\title{
Implication of plant growth-promoting rhizobacteria of Bacillus spp. as biocontrol agents against wilt disease caused by Fusarium oxysporum Schlecht. in Vicia faba L.
}

https://doi.org/10.1515/bmc-2021-0020

received November 30, 2021; accepted December 20, 2021.

\begin{abstract}
Out of seven Fusarium spp. isolated from infected faba bean roots, two Fusarium oxysporum were selected and showed faba bean-wilt disease severity with percentages of $68 \%$ and $47 \%$ under greenhouse conditions. The F. oxysporum showed the highest wilt disease was selected to complete the current study. Three rhizobacterial strains were isolated and identified as Bacillus velezensis $\mathrm{Vb1}$, B. paramycoides $\mathrm{Vb} 3$, and B. paramycoides Vb6. These strains showed the highest in-vitro antagonistic activity by the dual-culture method against selected $F$. oxysporum with inhibition percentages of $59 \pm 0.2,46 \pm 0.3$, and $52 \pm 0.3 \%$ for $\mathrm{Vb} 1, \mathrm{Vb} 3$, and $\mathrm{Vb} 6$, respectively. These rhizobacterial strains exhibit varied activity for nitrogenfixing and phosphate-solubilizing. Moreover, these strains showed positive results for ammonia, HCN, and siderophores production. The phytohormones production (indole-3-acetic acid, ABA, benzyl, kinten, ziaten, and $\mathrm{GA}_{3}$ ) and secretion of various lytic enzymes were recorded by these strains with varying degrees. Under greenhouse conditions, the rhizobacterial strains $\mathrm{Vb1}, \mathrm{Vb} 3, \mathrm{Vb} 6$, and their consortium can protect faba bean from wilt caused by $F$. oxysporum with percentages of $70,60,65$, and $82 \%$, respectively. Under field conditions, the inoculation with the rhizobacterial consortium (Vb1+Vb3+Vb6)
\end{abstract}

\footnotetext{
*Corresponding authors: Saad El-Din Hassan, Amr Fouda, Botany and Microbiology Department, Faculty of Science, Al-Azhar University, Cairo 11884, Egypt, E-mails: saad.el-din.hassan@ umontreal.ca; amr_fh83@azhar.edu.eg Mostafa Mohamed El-Sersawy, Amr Mahmoud Abd El-Gwad, Soil Fertility and Microbiology Department, Desert Research Center, ElMataria, Cairo, Egypt

Abbas A. El-Ghamry, Botany and Microbiology Department, Faculty of Science, Al-Azhar University, Cairo 11884, Egypt
}

significantly increases the growth performance of the F. oxysporum-infected faba bean plant and recorded the highest wilt protection (83.3\%).

Keywords: Fusarium wilt; Fusarium oxysporum; plant growth-promoting; Vicia faba; greenhouse experiment; field experiment.

\section{Introduction}

Increased human populations combined with restricted agricultural land availability have a significant impact on food security. By 2050, the world's population is predicted to exceed 9 billion people, resulting in a $70 \%$ rise in food demand [1]. Agricultural production has increased since the green revolution and farmers have relied on chemical fertilizers to ensure economic stability [2]. However, its deleterious effects on environmental ecology and human cannot be denied. Chemical fertilizers can aid plant growth, but do not play a role in improving soil properties [3]. They are responsible for degrading the soil by lowering its water holding capacity, rising salinity, and creating nutritional disparities [4]. Due to bioaccumulation and biomagnification of various harmful substances, their excessive usage pollutes the ecosystem $[5,6]$. Natural radionuclides such as mercury, cadmium, and lead as well as various chemicals insecticides are absorbed by plants through the soil and eventually enter the food chain [7, 8]. Stomach cancer, vector-borne infections, and methemoglobinemia have all been linked to the accumulation of these toxins in newborns and humans [9]. Given all the negative impacts of chemical inputs and the growing public concern about them, alternative soil fertilization options are urgently needed. The global 
challenge is how can current agricultural practices meet the argent food demand without dependence on higher inputs of inorganic chemical fertilizers [10]. Microorganisms are an example of a viable option that can boost plant development and output while also preserving soil fertility. This is accomplished by taking advantage of plant-microbe interactions in the rhizosphere [11].

Plant growth-promoting rhizobacteria (PGPR) are an essential component of organic farming, they live in the rhizosphere and play a crucial role in soil productivity, plant growth, and disease suppression [12]. Pseudomonas, Klebsiella, Azoarcus, Enterobacter, Azospirillum, Azotobacter, Rhizobium, Bacillus, and Serratia are the most common described PGPR genera [11, 13]. Their diversity varies depending on soil type and circumstances, plant type, and nutrient accessibility in the rhizosphere [14]. Although various soil microorganisms are plant growth-promoting, not all strains belonging to a specific genus and species have equivalent hereditary makeup and metabolic competencies [15]. PGPRs are commercially made available in the form of microbial formulations called bio-fertilizers which can be applied directly onto seeds or introduced into the plant rhizosphere wherein they colonize and provide nutritive benefits to the host plant [16]. They are a safe alternative to conventional chemical fertilizers and provide sustainable agricultural production worldwide. Biofertilizer treatment results in improved plant growth in terms of seed germination, shoot and root development, increased biomass, and reduced disease incidence [17].

Faba bean (Vicia faba L.) is an important and useful legume that provides food and feed to humans all over the world. It is rich in high-quality protein, energy, fiber, and micronutrients especially $\mathrm{Fe}, \mathrm{Zn}$, and pro-vitamin $\mathrm{A}$; and possesses compounds capable of preventing disease and promoting health. This legume is affected by various biotic and abiotic stresses which severely limited its yield. Considering the world's growing population and the necessity for food crops that are best suited to humanity's health, legumes will be in great demand, including common beans, mainly because of their nutritional value. In recent years, the area planted with beans has increased due to its various advantages, including profitability, rotational crop with cereals, atmospheric nitrogenfixation, and high protein food. The factors that induce the inhibition of fungal invasion of plant roots are complex and poorly understood. A variety of agroecological factors such as the growth stage of the host plant, soil properties, and agronomic practices can influence root colonization by the fungus. Fusarium oxysporum, causing Fusarium wilt in many crops $[18,19]$.
Fusarium wilt caused by Fusarium oxysporum Schlechtend.Fr. f. sp. Phaseoli (Fop) is one of the most important bean diseases, being present in all crop production areas worldwide [20]. Fusarium wilt symptoms include foliar chlorosis, premature defoliation of lower leaves, red-brown necrosis of vascular tissue, wilting, and plant death [21]. Fop infects bean plants through wounds, natural openings, or intact roots, preferentially at the junctions of the lateral roots and the taproot [20]. During the infection, hyphae grow intracellularly in the root cortex until they reach the xylem vessels [20, 22]. The development of disease symptoms and degree of colonization in xylem vessels varied greatly among genotypes. Therefore, checking how far upward the pathogen is in the vessels from the roots might be useful to confirm the resistance of inoculated bean plants. This study focuses on the application of soil bacteria as a biocontrol agent against wilt disease caused by Fusarium oxysporum Schlecht. in Vicia faba L. To end with this goal, pathogenic soilborne fungus of Fusarium oxysporum was isolated from the naturally infected bean plants. Rhizospheric soil bacteria were isolated from the soil of healthy bean plants, bacteria that showed better plant growth-promoting capacity along with their antagonistic characteristics were then chosen to be applied as biocontrol agents against wilt disease caused by Fusarium oxysporum under greenhouse and field experiments.

\section{Material and methods}

\section{Isolation of Fusarium pathogen from infected faba bean}

The Fusarium oxysporum was isolated from roots of naturally infected faba bean plants showing symptoms of wilt disease. The infected plants were collected from the North Sinai governorate, Egypt. The infected roots were subjected to surface sterilization by $2 \%$ sodium hypochlorite for $2 \mathrm{~min}$, rinsed twice with sterilized distilled water, and kept for drying under aseptic conditions. The sterilized roots were cut into small pieces $(0.5 \mathrm{~cm})$ and immersed on Petri dishes containing potato dextrose agar (PDA) media (containing g L ${ }^{-1}$ : potato, 200; dextrose, 20; agar, 15; 1.0 L distilled $\mathrm{H}_{2} \mathrm{O}$ ) and incubated for seven days at $25 \pm 2^{\circ} \mathrm{C}$. The inoculated plates were examined for pure colonies and a single spore was sub-cultured onto new PDA plates. 


\section{Identification of Fusarium spp.}

The Fusarium spp. cultured were identified based on cultural followed by morphological characteristics and confirmed by macro- and micro-conidial structure [23-25].

\section{Pathogenicity test for F. oxysporum.}

The pathogenicity test of two stains of $F$. oxysporum was achieved at EL-Qantra Sharq Experimental Station of Desert Research Center (D.R.C.), North Sinai Governorate, Egypt (31 $01^{\circ} 21.6^{\prime \prime} \mathrm{N}$ and $\left.32^{\circ} 33^{\prime} 48.1^{\prime \prime} \mathrm{E}\right)$ as greenhouse experiment. The pathogenic capabilities were tested using Maryot-2 faba bean cultivar collected from Agricultural Research Center, Giza, Egypt. The Fusarium inocula were prepared by inoculation of each fungal strain into potato dextrose broth media and incubated at $25 \pm 2^{\circ} \mathrm{C}$ for 15 days. The sandy-loam soil used in this experiment was autoclaved, added to sterilized pots $(2 \mathrm{~kg} / \mathrm{pot})$, and mixed thoroughly with fungal inoculation $(2 \%)$. The physicochemical analysis of used soil is illustrated in Table 1. The seeds of collected faba bean were surface sterilized using 2\% sodium hypochlorite for $4 \mathrm{~min}$., washed in distilled water. Each pot was sown with three sterilized faba bean seeds. Pots without $F$. oxysporum inoculation and sown with sterilized faba bean seeds were running with the experiment as a control. The experiment was achieved in triplicates. The greenhouse condition was standardized throughout the experiment at a temperature between 18 to $24^{\circ} \mathrm{C}$. The plants were irrigated as necessary and observed for diseases development.

\section{Disease severity assessment.}

The wilting percentage caused by each $F$. oxysporum was assessed after 60 days from planting, based on leaf yellowing and/or root discoloration. The symptoms of typical wilt due to Fusarium infection are numerically assessed according to their severity in ranging between 0 to 5 as follows: (0) mean no wilt symptoms appeared; (1) mean approximately from 1 to $20 \%$ of vascular plant systems are light brown and the plant leaves appear as yellow; (2) mean approximately from 20 to $40 \%$ of vascular plant systems are light brown and the plant leaves appear as yellow; (3) mean approximately from 40 to $60 \%$ of vascular plant systems are dark brown and the plant leaves appear as yellow; (4) mean approximately from 60 to $80 \%$ of vascular plant systems are dark brown and the plant leaves appear as yellow; (5) mean approximately from
80 to $100 \%$ of the leaves are yellowish and the vascular systems are dark brown or completely dead plants.

The disease severity was calculated according to the following equation [26]:

$$
\text { Disease severity }=\frac{\sum[(\mathrm{N} 0)+(\mathrm{N} 1)+(\mathrm{N} 2)+(\mathrm{N} 3)+(\mathrm{N} 4)+(\mathrm{N} 5)]}{5 \mathrm{~T}}
$$

Where: $(\mathrm{N})$ means the number of plants corresponding to the symptom grade, (0), (1), (2), (3), (4), and (5); (5T) mean the total number of plants (T) multiplied by maximum symptom grade (5).

\section{Isolation of bacterial rhizospheres.}

To isolate different bacterial species from rhizosphere soil of healthy faba bean plant, approximately $10 \mathrm{~g}$ of collected rhizosphere soil was mixed with $100 \mathrm{~mL}$ sterilized distilled water and stirred for $10 \mathrm{~min}$. After that, the serial dilution was made up to $10^{-7}$ and inoculate $0.1 \mathrm{~mL}$ of final dilution into nutrient agar media. The inoculated plates were incubated at $35 \pm 2^{\circ} \mathrm{C}$ for $24 \mathrm{~h}$. The different morphological bacterial colony was re-streaked onto new nutrient agar plates to confirm the purity. The purified isolates are inoculated onto nutrient agar slant and kept in a refrigerator at $4^{\circ} \mathrm{C}$ for further study.

\section{Selection of the most potent bacterial isolates}

The most potent bacterial isolates were selected based on their highest efficacy to inhibit the growth of Fusarium oxysporum by using the in-vitro dual culture assay method [27]. Each rhizospheric bacterial isolate was inoculated at three equidistant points on the PDA plate and incubated at $35 \pm 2^{\circ} \mathrm{C}$ for $24 \mathrm{~h}$. At the end of the incubation period, a disk ( $5 \mathrm{~mm}$ ) of a 7-days-old culture of $F$. oxysporum was put in the center of bacterial inoculated PDA plates. The control was designated as a PDA plate containing a disk of $F$. oxysporum without bacterial inoculation and running with the experiment under the same conditions. The plates were incubated at $28 \pm 2^{\circ} \mathrm{C}$ for five days. The fungal growth inhibition percentage was calculated using the following equation:

$$
\text { Growth inhibition }(\%)=\frac{\mathrm{R} 1-\mathrm{R} 2}{\mathrm{R} 1} \times 100
$$

Where $\mathrm{R} 1$ is the radial growth of $F$. oxysporum in absence of bacterial isolate (control), while $\mathrm{R} 2$ is the radial growth 
Table 1: Physical and chemical characters of soil and organic fertilizer used in the current study.

\begin{tabular}{|c|c|c|c|}
\hline \multirow{2}{*}{$\begin{array}{l}\text { Soil analysis } \\
\text { Characters }\end{array}$} & \multirow[b]{2}{*}{ Results } & \multicolumn{2}{|c|}{ Organic fertilizer analysis } \\
\hline & & Characters & Results \\
\hline Physical characters & & Density $\left(\mathrm{kg} / \mathrm{m}^{3}\right)$ & 670 \\
\hline Coarse sand (\%) & 56.58 & Relative humidity & 46.70 \\
\hline Fine Sand (\%) & 31.04 & $\mathrm{EC} \mathrm{mmhos} / \mathrm{cm}$ at $25^{\circ} \mathrm{C}$ & 13.56 \\
\hline Silt (\%) & 7.93 & $\mathrm{PH}\left(1-10 \mathrm{H}_{2} \mathrm{O}\right)$ & 8.40 \\
\hline Clay (\%) & 4.45 & Organic matter & 50.00 \\
\hline Soil texture & Loamy sand & Organic carbon & 29.00 \\
\hline Chemical characters & & $\mathrm{N}(\%)$ & 1.68 \\
\hline $\mathrm{pH}$ & 7.86 & $\mathrm{P}(\%)$ & 0.59 \\
\hline $\mathrm{EC}(\mathrm{Ds} / \mathrm{m})$ & 0.29 & $\mathrm{~K}(\%)$ & 4.78 \\
\hline O.M. (\%) & 0.59 & $\mathrm{Fe}(\mathrm{ppm})$ & 3310 \\
\hline O.C. (\%) & 0.34 & Zn (ppm) & 94.80 \\
\hline T.N. (\%) & 0.3 & $\mathrm{Cu}(\mathrm{ppm})$ & 48.15 \\
\hline $\mathrm{C} / \mathrm{N}$ ratio & 11.3 & $\mathrm{Mn}(\mathrm{ppm})$ & 264 \\
\hline \multicolumn{4}{|c|}{ Soluble Cations (meq L-1) } \\
\hline $\mathrm{Ca}^{++}$ & 4.9 & & \\
\hline $\mathrm{Mg}^{++}$ & 2.2 & & \\
\hline $\mathrm{Na}^{+}$ & 8.3 & & \\
\hline $\mathrm{K}^{+}$ & 0.9 & & \\
\hline \multicolumn{4}{|c|}{ Soluble anions (meq L-1) } \\
\hline $\mathrm{HCO}_{3}^{-}$ & 3.1 & & \\
\hline $\mathrm{Cl}^{-}$ & 6.7 & & \\
\hline $\mathrm{SO}_{4}^{--}$ & 5.7 & & \\
\hline
\end{tabular}

EC is electrical conductivity; O.M. denotes the organic matter percent; O.C. denotes the organic carbon; T.N denotes the total nitrogen; C/N denotes the carbon to nitrogen percent.

of $F$. oxysporum in presence of bacterial isolate. The experiment was achieved in triplicate for each bacterial isolate.

\section{Identification of the most potent bacterial isolates.}

The most potent bacterial isolates designated as Vb1, $\mathrm{Vb3}$, and Vb6 were identified based on sequencing and amplification of the $16 \mathrm{~S}$ rRNA gene. The genomic DNA was extracted according to the modified method [28]. Briefly, a separate bacterial colony was picked up by a sterile toothpick and suspended in $50 \mu \mathrm{L}$ of sterilized deionized water. The cell suspension was put in a water bath for 10 $\min$ at $97^{\circ} \mathrm{C}$, after that, the suspension was centrifuged for $10 \mathrm{~min}$ at $15000 \mathrm{rpm}$ to recover the upper layer that contains the DNA. The intensity of DNA in the collected layer was calculated by measuring its absorbance at $260 \mathrm{~nm}$ by UV-spectrophotometer. A bacterial universal primers 27f (5'-AGAGTTTGATCCTGGCTCAG-3') and 1492r (5'-GGTTACCTTGTTACGACTT-3') were used to PCR amplification of the 16S rDNA fragment. The PCR tube containing PCR buffer $(1 \mathrm{x}), \mathrm{MgCl}_{2}(0.5 \mathrm{mM})$, Tag DNA polymerase (2.5 U, QIAGEN Inc.), Deoxynucleoside triphosphate (dNTP, $0.25 \mathrm{mM})$, universal primer $(0.5 \mu \mathrm{M})$, and bacterial DNA ( $5 \mathrm{ng}$ ). The PCR cycling conditions were $94^{\circ} \mathrm{C}$ for three minutes, followed by 30 cycles at $94^{\circ} \mathrm{C}$ for 
30 seconds, $55^{\circ} \mathrm{C}$ for 30 seconds, $72^{\circ} \mathrm{C}$ for 60 seconds, and final extension at $72^{\circ} \mathrm{C}$ for ten minutes. The forward and reverse sequencing for PCR products was achieved using Applied Biosystem's 3730xl DNA Analyzer technology at Sigma company, Cairo, Egypt.

The obtained sequences were analyzed using BLAST as compared with those deposited in the GeneBank database. Multiple sequence alignment was performed using ClustalX 1.8 software package and a phylogenetic tree was constructed by the neighbor-joining method using MEGA (Version 6.1) software. The confidence level of each branch (1000 repeats) was tested by bootstrap analysis. The sequences obtained in the current study were deposited at GeneBank under accession numbers LC571587, LC571588, LC 571589 for strains Vb1, Vb3, and Vb6 respectably.

\section{Characterization of the most potent rhizospheric bacterial strains as plant growth-promoting}

\section{Nitrogen fixation}

\section{A- Qualitative screening}

The primary screening to investigate the efficacy of the most potent rhizospheric bacterial strains to nitrogenfixing was achieved through streaking on nitrogen-free malate medium (containing $\mathrm{L}^{-1}$ : yeast extract, $0.1 ; \mathrm{KH}_{2} \mathrm{PO}_{4}$, $0.4 ; \mathrm{NaCl}, 0.1 ; \mathrm{MgSO}_{4} \cdot 7 \mathrm{H}_{2} \mathrm{O}, 0.2 ; \mathrm{FeCl}_{3}, 0.1 ; \mathrm{Na}_{2} \cdot \mathrm{MoO}_{4} \cdot 2 \mathrm{H}_{2} \mathrm{O}$, 0.2; biotin, traces; $1.0 \mathrm{~L}$ distilled $\mathrm{H}_{2} \mathrm{O}$ ) supplemented with bromothymol blue as an indicator [29]. The inoculated plates were incubated at $35 \pm 2^{\circ} \mathrm{C}$ for $48 \mathrm{~h}$. The producing blue color around bacterial growth is designated as a positive nitrogen fixer. The results were recorded as positive or negative based on blue color formation.

\section{B- Quantitative bioassay using (acetylene reduction assay)}

Nitrogenase activity was determined separately by the method of acetylene reduction technique given by [30]. A number of tubes (3) containing medium were inoculated with single colonies from each different isolates and incubated for $72 \mathrm{~h}$ at $30^{\circ} \mathrm{C}$. After that, the tubes were closed with sub seal, ten percent of pure acetylene $\left(\mathrm{C}_{2} \mathrm{H}_{2}\right)$ was injected into the tubes which were incubated for 4 $\mathrm{h}$, and then 0.1 of gas samples were withdrawn for the determination of $\mathrm{C}_{2} \mathrm{H}_{4}$ formed using Hewlett-Packard 5890 gas chromatography Series 2 plus, fit with two flames; Ionization and electron capture detectors, electron pressure control system (EPC) and Hp-Plot $\mathrm{AL}_{2} \mathrm{O}_{3}$ capillary column (cross-linked $\left.\mathrm{AL}_{2} \mathrm{O}_{3}\right)\left(50 \mathrm{~m} \times 0.53 \mathrm{~mm}^{\star} 15.0 \mathrm{~mm}\right.$ film thickness) and attached with HP computer unit and printer. The applied temperatures were $170^{\circ} \mathrm{C}, 120^{\circ} \mathrm{C}$, and $200^{\circ} \mathrm{C}$ for injector, column, and detector, respectively. The carrier gas (nitrogen) at flow rate $10 \mathrm{ml} / \mathrm{min}$, hydrogen and air for flame ionization detector were at a rate of 30 and $300 \mathrm{ml} / \mathrm{min}$, respectively. Standard pure ethylene was diluted with air and acetylene and mixed in special containers to obtain concentrations ranging from 100 to $1000 \mathrm{ppm}$; this was used as a reference for calculating the ethylene concentration in the sample. Results were calculated as ethylene produced/ml liquid culture /day.

\section{Phosphate solubilization}

\section{A- Qualitative screening}

The efficacy of rhizospheric bacterial strains to solubilizing phosphate was primary screening according to Jasim et al. [31] using Pikovskaya agar media (containing $\mathrm{g}$ $\mathrm{L}^{-1}$ : glucose, 10; $\mathrm{Ca}_{3}\left(\mathrm{PO}_{4}\right)_{2}, 5$; $\left(\mathrm{NH}_{4}\right)_{2} \mathrm{SO}_{4}, 0.5 ; \mathrm{NaCl}, 0.2$; $\mathrm{MgSO}_{4} \cdot 7 \mathrm{H}_{2} \mathrm{O}, 0.1 ; \mathrm{KCl}, 0.2 ; \mathrm{FeSO}_{4} \cdot 7 \mathrm{H}_{2} \mathrm{O}, 0.002$; yeast extract, 0,$5 ; \mathrm{MnSO}_{4} \cdot 2 \mathrm{H}_{2} \mathrm{O}$, 0.002; agar, 15; $1.0 \mathrm{~L}$ distilled $\left.\mathrm{H}_{2} \mathrm{O}\right)$. Briefly, the bacterial strain was inoculated as spot on the center of Pikovskaya agar plate and incubated at 35 $\pm 2^{\circ} \mathrm{C}$ for $48 \mathrm{~h}$. The results were recorded as the diameter of the clear zone formed around each bacterial growth. The experiment was achieved in triplicates.

\section{B- Quantitative screening}

The quantitative phosphate solubilization was analyzed by measuring $\mathrm{pH}$ values and $\mathrm{P}$ concentration at interval times (2 - 10 days). Briefly, Pikovskaya's broth medium supplemented with $0.5 \% \mathrm{Ca}_{3}\left(\mathrm{PO}_{4}\right)_{2}$ was inoculated with rhizospheric bacterial strain and incubated at $35 \pm 2^{\circ} \mathrm{C}$ for 10 days on a rotary shaker at $180 \mathrm{rpm}$. Five $\mathrm{ml}$ samples were taken daily and centrifuged at $10,000 \mathrm{rpm}$ for 10 min. The phosphomolybdate method was used for the determination of available soluble phosphate in the culture supernatant using a spectrophotometer (Jenway $6305 \mathrm{UV}$ ) measuring at O.D. $700 \mathrm{~nm}$. The concentration of $P$ was calculated from the slope of the standard curve of P. Also, the $\mathrm{pH}$ of the broth medium was measured daily with a digital $\mathrm{pH}$ meter [32].

\section{Ammonia production}

The ability of rhizospheric bacterial strains to produce ammonia was assessed in peptone water broth. Each 
bacterial strain was inoculated into tubes containing 10 $\mathrm{mL}$ peptone water and incubated at $35 \pm 2^{\circ} \mathrm{C}$ for $48 \mathrm{~h}$. At the end of the incubation period, approximately, $0.5 \mathrm{~mL}$ of Nessler's reagent was added to culture broth media. The development of yellow color was recorded as,,++++++ based on the color intensity [33].

\section{Extracellular Enzymatic Activities}

The productions of extracellular enzymes (amylase, cellulase, protease, and catalase) of the rhizospheric bacterial strains were investigated by inoculating the isolates in a mineral salt (MS) agar media (containing $\mathrm{g}$ $\mathrm{L}^{-1}: \mathrm{NaNO}_{3}, 5 ; \mathrm{KH}_{2} \mathrm{PO}_{4}, 1 ; \mathrm{K}_{2} \mathrm{HPO}_{4}, 2 ; \mathrm{MgSO}_{4} .7 \mathrm{H}_{2} \mathrm{O}, 0.5 ; \mathrm{KCl}$, 0.1; $\mathrm{CaCl}_{2}, 0.01$; $\mathrm{FeSO}_{4} .7 \mathrm{H}_{2} \mathrm{O}, 0.02$; agar, 15; distilled $\mathrm{H}_{2} \mathrm{O}$, 1L) supplemented with specific additives, depending on the enzyme being tested. The MS agar media without bacterial inoculation was running with the experiment as a negative control. After incubation at $35 \pm 2^{\circ} \mathrm{C}$ for $24 \mathrm{~h}$, specific reagents were added and the size of the clear zone $(\mathrm{mm})$ surrounding the bacterial colony was measured, indicating extracellular enzymatic activities. All assays were performed in triplicates. For amylolytic and cellulolytic activities, the bacterial strains were inoculated onto MS agar medium supplemented with $1 \%$ soluble starch and 1\% carboxy-methylcellulose (CMC) respectively. After the incubation period, the plates were flooded with $1 \%$ iodine. For protease activity, the MS agar medium containing $1 \%$ gelatin was used to determine the proteolytic activity of the bacteria. After incubation period, gelatin degradation was checked using acidic mercuric chloride as an indicator [34, 35].

For catalase activity, the pure bacterial colony from young culture (18-24h.) was put into a glass slide and mixed with a few drops of $3 \% \mathrm{H}_{2} \mathrm{O}_{2}$. The appearance of oxygen bubbles indicates the presence of catalase activity [36].

\section{Siderophore production}

Secretion of siderophore was qualitatively analyzed using king's B agar medium containing chrome azurol $\mathrm{S}$ as an indicator dye, $\mathrm{Fe}^{3+}$ solution, and hexadecyltrimethylammonium bromide (HDTMA). The fresh bacterial culture was spotted onto a king's B agar plate and incubated at $28^{\circ} \mathrm{C}$ for $72 \mathrm{~h}$. The appearance of an orange halo around the bacterial growth indicates a positive siderophore production [37].

\section{HCN production}

The purified rhizospheric bacterial isolate was tested for HCN production through inoculation on king's B agar medium amended with glycine [38]. After that, a Whatman No. 1 filter paper was soaked in a solution of ( $2 \%$ sodium carbonate mixed with $0.05 \%$ picric acid solution) and put on the lid of inoculated king's B petri dish. The plates were sealed with parafilm and incubated at $28 \pm 2^{\circ} \mathrm{C}$ for $48 \mathrm{~h}$. The change in the color of the filter paper from deep yellow to reddish-brown color indicates a positive result for $\mathrm{HCN}$ production.

\section{IAA production}

\section{A- Qualitative screening.}

The most potent rhizospheric bacterial isolates were screened for qualitative IAA production. Briefly, the bacterial isolates are inoculated into nutrient broth media amended with different concentrations of tryptophan $(0$, 1,2 , and $5 \mathrm{mg} \mathrm{mL}^{-1}$ ) and incubated at $35 \pm 2^{\circ} \mathrm{C}$ for 15 days. At the end of the incubation period, the inoculated culture was centrifuged at $3000 \mathrm{rpm}$ for $30 \mathrm{~min}$. After that, two $\mathrm{mL}$ of the obtained supernatant was mixed with 2 drops of orthophosphoric acid and $4 \mathrm{~mL}$ of Salkowski's reagent (300 $\mathrm{mL}$ concentrated Sulfuric acid: $500 \mathrm{~mL}$ distilled water: 15 $\mathrm{mL} 0.5 \mathrm{M} \mathrm{FeCl}_{3}$ ). The development of pink color indicates successful IAA production. The intensity of the formed color was measured at $530 \mathrm{~nm}$ using a spectrophotometer (T60 UV-Visible spectrophotometer) [39]. The amount of IAA was estimated via a standard IAA graph to detect the best tryptophan concentration for IAA production.

\section{B- Quantitative assay}

For quantitative IAA assay, the rhizospheric bacterial isolates were inoculated in nutrient broth media supplemented with $5 \mathrm{mg} \mathrm{mL}^{-1}$ of tryptophan (the best concentration of tryptophan for IAA production based on qualitative screening) and incubated at $35 \pm 2^{\circ} \mathrm{C}$ for 14 days. Approximately two $\mathrm{mL}$ of inoculated culture was withdrawn after the $2^{\text {nd }}$ day up to the $14^{\text {th }}$ day with 2 days interval and centrifuged at $3000 \mathrm{rpm}$ for 30 minutes. One $\mathrm{mL}$ of the supernatant was mixed with 1 drop of orthophosphoric acid and $2 \mathrm{~mL}$ of Salkowski's reagent. The intensity of development of pink color was measured at $530 \mathrm{~nm}$ using a spectrophotometer [39]. The amount of IAA produced was estimated by the standard IAA graph to detect the best days for IAA production. 


\section{Detection of other phytohormones}

The three most potent rhizospheric bacterial isolates were screened for their ability to produce other phytohormones including gibberellic acids $\left(\mathrm{GA}_{3}\right)$, abscisic acid (ABA), benzyl, kinten, and ziaten. The bacterial isolates were grown in Ashby's medium (containing g L $\mathrm{L}^{-1}$ : mannitol, 10; sucrose, $5 ; \mathrm{K}_{2} \mathrm{HPO}_{4}, 0.5 ; \mathrm{NaCl}, 0.2 ; \mathrm{MgSO}_{4} \cdot 7 \mathrm{H}_{2} \mathrm{O}, 0.2 ; \mathrm{CaCO}_{3}$, $0.5 ; \mathrm{CaSO}_{4}, 0.1 ; \mathrm{FeCl}_{3}, 0.001 ; \mathrm{MnSO}_{4} \cdot 2 \mathrm{H}_{2} \mathrm{O}, 0.001 ; \mathrm{Na}_{2}$. $\mathrm{MoO}_{4} \cdot 2 \mathrm{H}_{2} \mathrm{O}, 0.002 ; 1.0 \mathrm{~L}$ distilled $\mathrm{H}_{2} \mathrm{O}$ ) and incubated at $30 \pm 2^{\circ} \mathrm{C}$ for 7 days. Then the ability of the growing cultures to produce phytohormones is well determined quantitatively by high-performance liquid chromatography (HPLC) as previously reported [40].

\section{Biocontrol of Fusarium wilt in Vicia faba plant using rhizosphere bacterial isolates}

\section{Greenhouse experiment.}

\section{A. Experimental Design.}

The pot experiment using a completely randomized design and three replicates for each treatment was achieved to investigate the efficacy of rhizospheric bacterial isolates (Vb1, Vb3, and Vb6) to reduce the incidences of Fusarium wilt in faba bean plants under greenhouse conditions. The soil used in the greenhouse experiment was collected from EL-Qantra Sharq Experimental Station of Desert Research Center (D.R.C.), North Sinai Governorate, Egypt (Table 1). The Maryot-2 faba bean cultivar and their surface sterilization were achieved as mentioned in the pathogenicity test.

\section{B. Bacterial inoculations}

The three bacterial species were inoculated into nutrient broth media separately or in a consortium and incubated for $24 \mathrm{~h}$ at $35 \pm 2^{\circ} \mathrm{C}$. The sterilized faba bean seeds were subjected to pre-germination to check their health and divided into five groups, each group containing four similar germination seeds were selected. Four groups were soaked in $100 \mathrm{ml}$ of bacterial culture $\left(6 \times 10^{9} \mathrm{cell} / \mathrm{ml}\right)$ that were grown individually or in a consortium, whereas the fifth group of pre-germinated seeds was soaked in the un-inoculated bacterial culture as a control. All soaked pre-germinated seeds are incubated for $6 \mathrm{~h}$ at $35 \pm 2^{\circ} \mathrm{C}$ and sown in pots filled with $2 \mathrm{~kg}$ of sterilized soil. Each pot receives 3 pre-germinated seeds. The most pathogenic $F$. oxysporum was inoculated onto $100 \mathrm{ml}$ of PD broth media and incubated at $25 \pm 2^{\circ} \mathrm{C}$ for 15 days. At the end of the incubation period, the inoculated PD broth media was centrifuged, and the obtained pellets were resuspended in $100 \mathrm{ml}$ distilled water (adjusted at $5 \times 10^{5}$ conidia/ml) which was used as an inoculum for soil after one week of planting. The plants were irrigated as necessary and daily observed to check the infection. Disease severity percentages were estimated after 60 days post-sowing [41]. The percentages of reduction in the incidence of Fusarium wilt were calculated as follow:

$$
\text { Reduction percentages }(\%)=\frac{A-B}{A} \times 100
$$

Where A is disease incidence of positive control, B is disease incidence of treatment.

\section{Field experiment.}

\section{A. Experimental Design.}

The field trials were conducted at the EL-Qantra Sharq Experimental Station of Desert Research Center (D.R.C.), North Sinai Governorate, Egypt. The physical and chemical analysis of soil was represented in Table 1. The field experimental design was achieved using a splitplot design, in which the distance between rows was 50 $\mathrm{cm}$, while the distance between different plants on the same raw was $30 \mathrm{~cm}$ and the distance between different treatments was $1.0 \mathrm{~m}$. The experiment was carried out using 6 replicates for each treatment with an area of $3 \mathrm{~m}$ for every plot. The drip irrigation was used as an irrigation system during the experiment. The organic fertilization was added for the first time before planting and mixed well with the soil. The chemical and physical composition of organic fertilizer is shown in Table 1. On the other hand, inorganic fertilization was added (full doses) as recommended by the Ministry of Agriculture and Land Reclamation, Cairo, Egypt. The inorganic fertilizer consists of ammonium sulfate $(20.5 \% \mathrm{~N})$ as nitrogen fertilizer, calcium superphosphate $\left(15.5 \% \mathrm{P}_{2} \mathrm{O}_{5}\right)$ as phosphorus fertilizer, and potassium sulfate $\left(48 \% \mathrm{~K}_{2} \mathrm{O}\right)$ as potassium fertilizer. The inorganic fertilization was added at three periods as follows: immediately after planting, after 30 days, and after 40 days of planting.

\section{B- Inoculation, planting, and samples analysis}

Before the experiment, the faba bean seeds were subjected to surface sterilization and pre-germination to select the seeds with the same radical length. The three bacterial 
isolates (Vb1, $\mathrm{Vb} 3$, and $\mathrm{Vb6}$ ) were inoculated into nutrient broth media and incubated at $35 \pm 2^{\circ} \mathrm{C}$ for $24 \mathrm{~h}$. At the end of the incubation period, the selected seeds were incubated with bacterial suspension $\left(10^{9} \mathrm{CFU} \mathrm{mL}^{-1}\right)$ for $6 \mathrm{~h}$ which was picked up and planted into the soil. After one week of planting, approximately $20 \mathrm{ml}$ of Fusarium oxysporum suspension $\left(5 \times 10^{5}\right.$ conidia $\left./ \mathrm{ml}\right)$ was added beside the seedling roots. The different treatments were conducted as follows: (1) seeds without any treatment (healthy control), (2) seeds planting into soil infected with $F$. oxysporum (infected control), (3) seeds treated with $\mathrm{Vb1}$ and planting in soil infested with $F$. oxysporum,( 4) seeds treated with Vb3 and planting in soil infested with $F$. oxysporum, (5) seeds treated with Vb6 and planting in soil infested with $F$. oxysporum, (6) seeds treated with the bacterial consortium (Vb1 + Vb3) and planting in soil infested with F. oxysporum, (7) seeds treated with the bacterial consortium (Vb1 + Vb6) and planting in soil infested with F. oxysporum, (8) seeds treated with the bacterial consortium $(\mathrm{Vb} 3+\mathrm{Vb} 6)$ and planting in soil infested with $F$. oxysporum, (9) seeds treated with the bacterial consortium $(\mathrm{Vb} 1+\mathrm{Vb} 3+\mathrm{Vb} 6)$ and planting in soil infested with $F$. oxysporum.

After 60 days of sowing, the plant height $(\mathrm{cm})$, number of pods per plant, fresh weight, and dry weight of plant (g) were also recorded. Moreover, the disease root rot/wilt severity and reduction percentages were recorded as mentioned above after 60 days of planting [41].

\section{Statical analysis}

The layout of the experiment was a split-plot design. The experiment included three replicates for each treatment. Data were subjected to statistical analysis by a statistical package SPSS v17. The mean difference comparison between the treatments was analyzed by analysis of variance (ANOVA) and subsequently by Turkey's HSD (honestly significant difference) test at $p<0.05$.

\section{Result and Discussions}

\section{Isolation and identification of pathogenic Fusarium spp.}

Faba bean (Vicia faba L.) is considered one of the most important legume crops, grown overall in the world to be used as human food and animal feed [42]. The significant losses in faba bean yield can be related to fungal infections which cause root rot, damping-off, and wilt diseases [43]. The most common fungal species that destroy faba bean growth and hence cause significant yield losses are Fusarium species [44]. Therefore, seven Fusarium spp. were isolated from the naturally infected root of faba bean collected from Sinai governorate, Egypt. The obtained Fusarium spp. were identified based on morphological and cultural characteristics as Fusarium proliferatum, Fusarium subglutinans, Rhizoctonia solani, Fusarium solani (two isolates), and Fusarium oxysporum (two isolates).

Fusarium oxysporum is considered the main phytopathogen that causes Fusarium wilt and can be remain to exist in the soil for several years without a main host; therefore, it is difficult to control the disease caused by Fusarium [45]. In the current study, the pathogenic severity for two $F$. oxysporum strains to cause wilt disease in faba bean was estimated under greenhouse experiment. Data analysis showed that the percentages of disease severity due to infection with two strains of $F$. oxysporum were $68 \%$ and $47 \%$ as compared with control. Therefore, we select the strain that causes the highest Fusarium wilt for further tests.

\section{Isolation and selection of the most potent rhizospheric bacterial isolates}

The interactions between rhizospheric bacterial species and the root system of plants have a positive impact on plant health, yield, and soil quality. These positive impacts can be attributed to the high efficacy of rhizospheric bacterial strains and secondary metabolites to increase the phosphate solubilization, nitrogen fixation, increase the availability of nutrients, ameliorate the biotic and abiotic stresses, biological control of phytopathogens, enhance the plant immunity through induced systematic resistance (ISR) [46]. In the current study, out of 23 bacterial species isolated from rhizosphere soil of healthy faba bean plant, seven bacterial isolates exhibited the efficacy to inhibit the growth of $F$. oxysporum using in-vitro dual culture assay with varying degrees ranging between $39.06 \pm 0.3$ and 59.1 \pm 0.2 . Among seven rhizospheric bacterial isolates, three isolates designated as Vb1, Vb3, and Vb6 showed the highest efficacy to inhibit $F$. oxysporum growth with reduction percentages of $59.1 \pm 0.2,46.4 \pm 0.3$, and $52.5 \pm 0.3$, respectively (Fig. 1). The in-vitro dual culture is a common assay method for preliminary investigation, in which the antagonistic activity was detected through measuring the inhibition percentage of radial mycelial growth towards the inoculated bacterial strains [47]. Consistent with our study, out of 35 rhizospheric bacterial isolates, five 


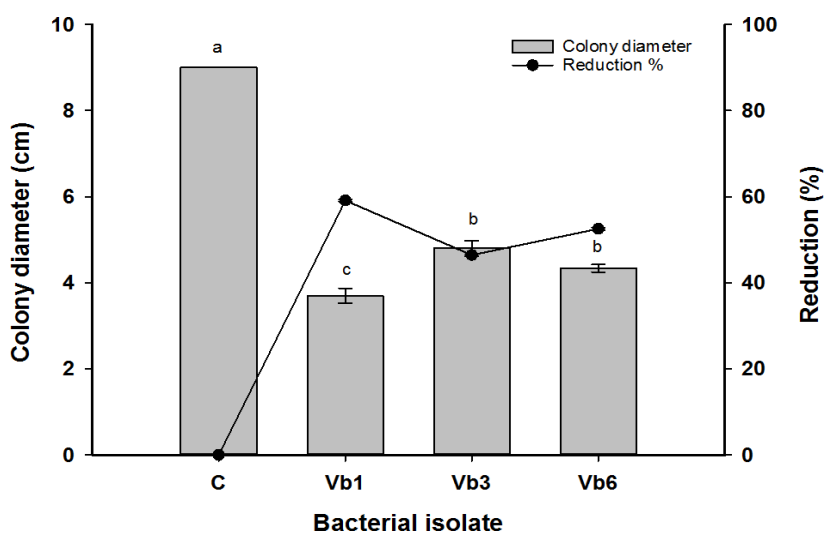

Figure 1: Antagonistic activity of the most potent bacterial isolates $\mathrm{Vb1}, \mathrm{Vb3}$, and $\mathrm{Vb6}$ against highest pathogenic F. oxysporum strain by in-vitro dual culture assay. Bars with the different letters are significantly different $(p \leq 0.05)$. Error bars indicate means $\pm \operatorname{SE}(n=3)$.

isolates exhibit $F$. oxysporum mycelial growth inhibition with varying percentages, and the bacterial isolate BA5 was the promising rhizospheric bacterial isolate to inhibit the mycelial growth with a percent of $58.3 \%$ [48]. Also, out of 100 microbial isolates obtained from rhizosphere soil samples, the bacterial isolate NJN-6 which was identified as Bacillus amyloliquefaciens showed the highest inhibition percentage towards F. oxysporum [49].

\section{Identification of the most potent bacterial isolates}

The three bacterial isolates designated as $\mathrm{Vb} 1, \mathrm{Vb} 3$, and $\mathrm{Vb} 6$ that exhibit high antagonistic activity with $F$. oxysporum were undergone identification based on amplification and sequencing of the $16 \mathrm{~S}$ rRNA gene. The sequence analysis showed that the isolates Vb1 have a similarity percentage of 99.7 with Bacillus velezensis, whereas the isolates $\mathrm{Vb3}$, and Vb6 have similarity percentages of 99.9 and $99.8 \%$ with two isolates of Bacillus paramycoides, respectively (Fig. 2). Similarly, the five rhizospheric bacterial isolates that showed high efficacy against Fusarium wilt, root rot, and crown diseases in tomatoes were identified using 16S rRNA as Acinetobacter calcoaceticus (AcDB3), B. amyloliquefaciens (BaMA26), B. siamensis (BsiDA2), B. subtilis (BsTA16), and B. thuringiensis (BtMB9) [50]. Accordingly, the Bacillus spp. are predominant rhizospheric bacterial species used to biocontrol of phytopathogenic fungi $[47,49,50]$. This phenomenon can be attributed to their different secondary metabolites and rapid growth which enables them to high integrate into biocontrol studies [51]. Recently, the cell immobilization of B. velezensis NH-1 was used to biocontrol of Fusarium wilt caused by F. oxysporum in cucumber [52]. Although the $B$. velezensis is a common bacterial species used in biocontrol, this is the first report for using it and $B$. paramycoides for biocontrol of Fusarium wilt caused by $F$. oxysporum in faba bean.

\section{Characterization of the rhizospheric bacterial strains as plant growth-promoting}

The antagonistic activity of rhizospheric bacterial species towards phytopathogenic fungi can be attributed to their plant growth-promoting traits. Among these traits, the efficacy of rhizospheric bacteria to producing hydrolytic enzymes, nutrient competitions, nitrogen fixations, siderophores production, phosphate solubilization, phytohormones production, and ammonia production [53]. The preliminary screening of three selected rhizospheric bacteria showed their efficacy to fixed nitrogen by producing blue color around the bacterial colony grown on nitrogen-free malate medium. The quantification nitrogen-fixing assay was achieved through the acetylene reduction method. Data on solid media (qualitative assay) are compatible with those recorded from liquid media (quantitative assay) after being analyzed by gas chromatography. Data analysis showed that the highest nitrogen-fixing was recorded for bacterial isolate $\mathrm{Vb} 1$ with the ethylene production value of $391.4 \pm 1.5 \mathrm{n}$ mole $\mathrm{C}_{2} \mathrm{H}_{4} /$ $\mathrm{ml} / 24 \mathrm{~h}$, followed by $\mathrm{Vb} 3$ and $\mathrm{Vb} 6$ with values of $351.8 \pm 1.2$ and 258.7 $\pm 1.01 \mathrm{n} \mathrm{mole}_{2} \mathrm{H}_{4} / \mathrm{ml} / 24 \mathrm{~h}$ (Table 2). Similarly, the nitrogen-fixing efficacy of rhizospheric bacterial species associated with Calligonum polygonoides and Lasiurus sindicus was assessed qualitatively via color change and quantitatively via acetylene reduction assay [29].

Another mechanisms utilized by rhizospheric microbes to enhance plant growth and then compete with phytopathogens are phosphate solubilization and ammonia production [54]. Among macronutrients required by a high amount for enhancement of plant growth is phosphorus ion, which exists in most cases as an insoluble form. Rhizospheric bacteria have the ability to convert phosphorus from insoluble to soluble form through different mechanisms such as the production of enzymes and /or organic acids [55]. In the current study, the appearance of a clear zone around the bacterial growth on Pikovskaya agar media indicates their success in phosphate solubilizing. The diameter of clear zones was $1.3 \pm 0.02,9.4 \pm 0.05$, and $9.9 \pm 0.12 \mathrm{~mm}$ for $\mathrm{Vb} 1, \mathrm{Vb} 3$, and $\mathrm{Vb} 6$, respectively (Table 2) which correlated with the amount of liberated phosphate. The quantitative assay is depending 


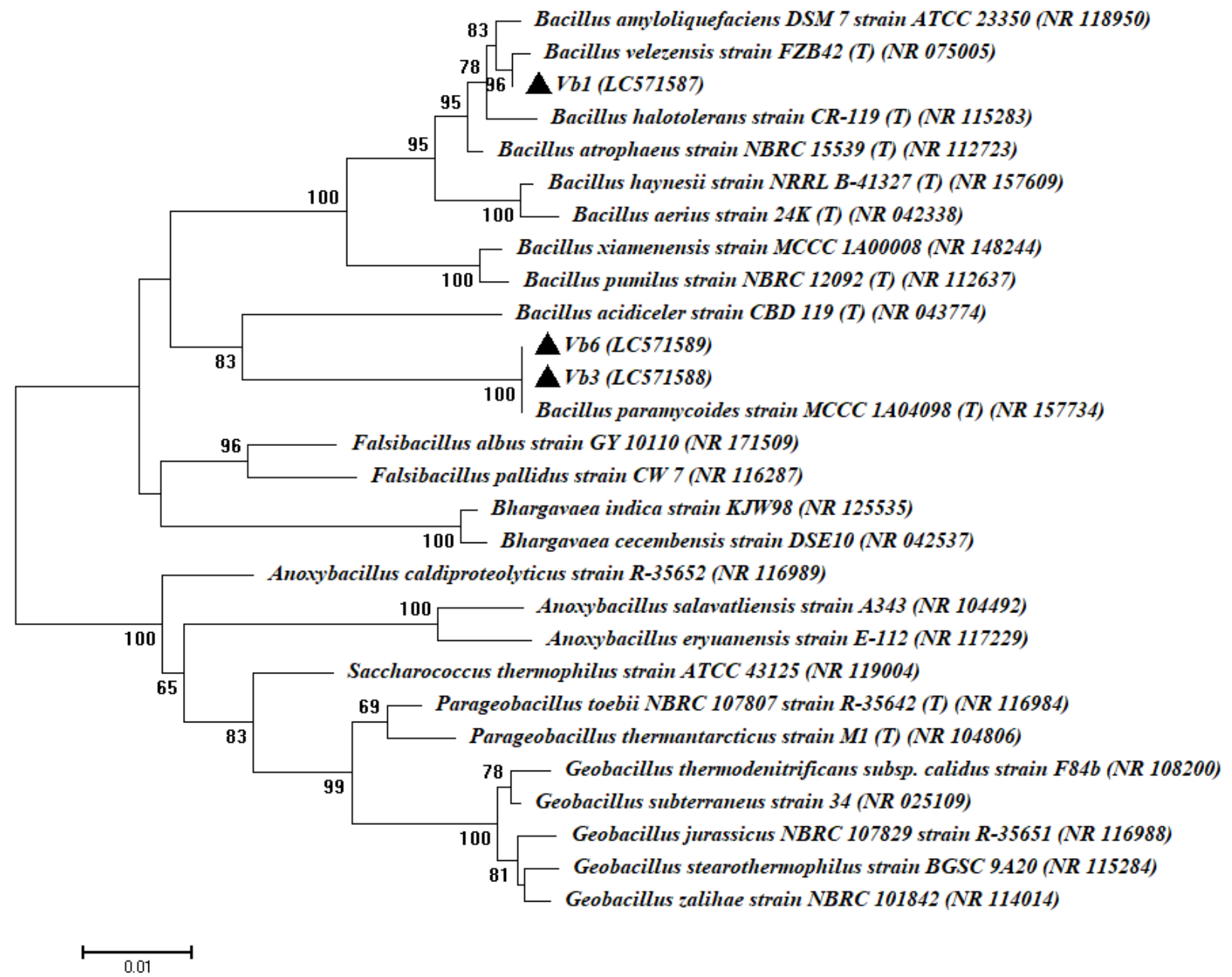

Figure 2: Phylogenetic analysis of 16sr RNA sequences of the bacterial isolates with the sequences retrieved from NCBI. The analysis was conducted with MEGA 7 using the neighbor-joining method with bootstrap value (1000 replicates).

Table 2: Characterization of selected rhizosphere bacterial strains Vb1, Vb3, and Vb6 as plant growth-promoting.

\begin{tabular}{|c|c|c|c|}
\hline \multirow[t]{2}{*}{ Test } & \multicolumn{3}{|c|}{ Rhizosphere bacterial isolate } \\
\hline & Vb1 & Vb3 & Vb6 \\
\hline Nitrogen fixation (n mole $\mathrm{C}_{2} \mathrm{H}_{4} / \mathrm{ml} / 24$ h.) & $391.44 \pm 1.46^{\mathrm{a}}$ & $351.84 \pm 1.17^{a}$ & $258.72 \pm 1.01^{b}$ \\
\hline Phosphorus solubilization (clear zone (mm)) & $1.3 \pm 0.02^{d}$ & $9.4 \pm 0.05^{\mathrm{a}}$ & $9.9 \pm 0.12^{a}$ \\
\hline Ammonia & + & ++ & + \\
\hline Amylase (mm) & $14 \pm 0.0^{\mathrm{a}}$ & 0.00 & $5.33 \pm 0.88^{b}$ \\
\hline Cellulase (mm) & $36 \pm 0.0 \mathrm{a}$ & $28.33 \pm 3.84 \mathrm{~b}$ & $30 \pm 1.53 \mathrm{~b}$ \\
\hline Protease $(\mathrm{mm})$ & $13 \pm 2.08^{\mathrm{a}}$ & $17.67 \pm 2.40^{\mathrm{a}}$ & $17.67 \pm 0.88^{a}$ \\
\hline Catalase & - & + & + \\
\hline Siderophore & + & + & + \\
\hline $\mathrm{HCN}$ & + & ++ & ++ \\
\hline
\end{tabular}

Values within the same row with different letters are significantly different $(p \leq 0.05)$, values are means $\pm \operatorname{SD}(n=3),-,+,++=$ negative, low, strong. 
on the amount of liberated organic acid detected by the phosphomolybdate method. The results showed that the highest phosphate solubilizing was achieved by bacterial isolate Vb6 followed by Vb3 and Vb1. Also, the difference between the amount of liberated phosphate recorded by bacterial isolates $\mathrm{Vb} 6$ and $\mathrm{Vb} 3$ are non-significant which recorded $91.5 \pm 1.2 \mu \mathrm{g} \mathrm{ml}^{-1}$ and $91.1 \pm 1.3 \mu \mathrm{g} \mathrm{ml}^{-1}$ respectively at $2^{\text {nd }}$ days and reached $152.2 \pm 1.3 \mu \mathrm{g} \mathrm{ml}^{-1}$ and $151.8 \pm 1.3 \mu \mathrm{g}$ $\mathrm{ml}^{-1}$ at tenth days (Fig. 3). The lowest amount of phosphate solubilization is recorded by bacterial strain $\mathrm{Vb1}$ which was $41.82 \pm 0.75 \mu \mathrm{g} \mathrm{ml}^{-1}$ after $2^{\text {nd }}$ days and decreased to $37.73 \pm 0.62 \mu \mathrm{g} \mathrm{ml}^{-1}$ after tenth days as compared with control which recorded $25.64 \pm 0.59 \mu \mathrm{g} \mathrm{ml}^{-1}$ and $27.31 \pm 0.49$ $\mu \mathrm{g} \mathrm{ml}^{-1}$ after second and tenth days, respectively (Fig. 3). According to the obtained data, the quantitative assay is compatible with those reported by the qualitative assay (formed clear zone). The production of low molecular weight organic acid is considered the main mechanism for phosphate solubilization by different bacterial species [56].

The obtained data highlighted that all rhizospheric bacterial isolates have the ability to produce ammonia with varying degrees according to color intensity after adding Nessler's reagent (Table 2). The highest intensity for brownish color was reported for isolate $\mathrm{Vb} 3$ followed by Vb1 and Vb6. Ammonia production enhanced plant growth by the synthesis of biomolecules containing nitrogen. Also, ammonia can increase the root and shoot length, enhance the fresh weight of the plants, and increase the efficacy of the plant against phytopathogens attacks [57].

The extracellular hydrolytic enzymes secreted by rhizospheric microbes are important for the decomposition of different polymers such as chitin, cellulase, starch, and lignin which ultimately to mineralization to beneficial minerals such as $\mathrm{P}, \mathrm{N}$, and $\mathrm{S}$ [58]. The secretion of these hydrolytic enzymes by different rhizosphere microbes has a critical role in the suppression of phytopathogenic fungi through the degradation of their cell wall $[59,60]$. For example, hydrolytic amylase, lipase, cellulase, pectinase, and protease enzyme are released by rhizospheric bacterial species such as Bacillus, Pseudomonas, and Enterobacter are showed inhibitory action against phytopathogenic fungi [61]. In the current study, the rhizosphere bacterial strains B. velezensis $\mathrm{Vb} 1, B$. paramycoides $\mathrm{Vb} 3$, and $B$. paramycoides Vb6 possess the efficacy to secret amylase, cellulase, protease, and catalase except the bacterial strains Vb3 and Vb1 lack the efficacy to secrete amylase and catalase (Table 2). Data analysis showed that the highest clear zone formed around bacterial strain was recorded for cellulase enzymes with values of $36 \pm 0.0,28.3 \pm 3.8$,

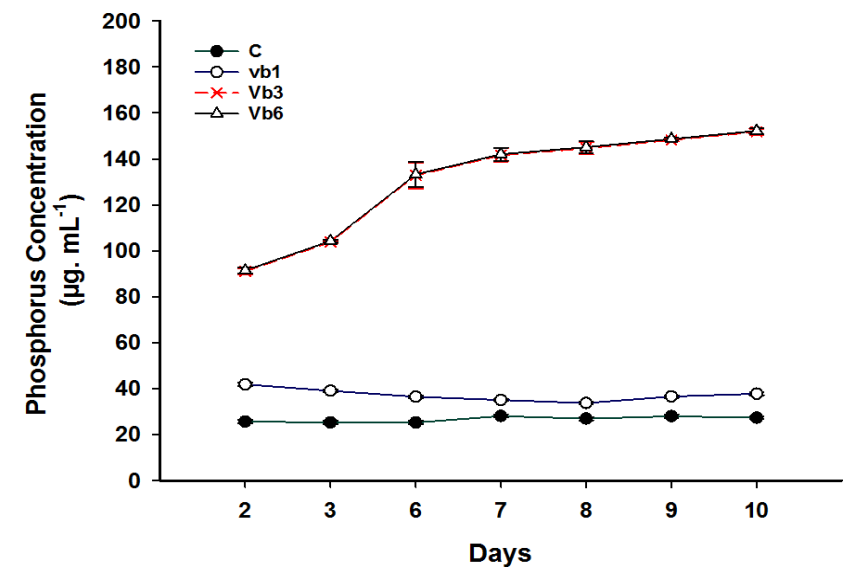

Figure 3: The amount of $\mathrm{P}$-liberated by rhizospheric bacterial strains $\mathrm{Vb1}, \mathrm{Vb} 3$, and $\mathrm{Vb} 6$ in liquid media.

and $30 \pm 1.53 \mathrm{~mm}$. Catalase enzymes promote plant growth by the indirect mechanism through scavenging the free radicals released because of biotic and abiotic stresses [36].

Siderophores have a critical role in the biocontrol of soilborne fungi as reported previously [62]. The inhibitory effect of siderophores against phytopathogenic fungi due to converting $\mathrm{Fe}^{3+}$ (inorganic form) to $\mathrm{Fe}^{2+}$ (organic form), and hence making it available for plant and unavailable for phytopathogens [63]. The selected bacterial strains $\mathrm{Vb} 1, \mathrm{Vb} 3$, and $\mathrm{Vb} 6$ are recorded as siderophores producers through the appearance of an orange halo around the bacterial growth. Similarly, Bacillus siamensis, B. subtilis, and B. amyloliquefaciens are characterized by their efficacy in producing siderophores which help in the biocontrol of Fusarium wilt caused by F. oxysporum [50]. Also, the efficacy of Pseudomonas aeruginosa JAS-25 to colonizing the roots, secretion of antibiotics, and antagonistic activity against pathogenic fungi can be related to their potentiality to siderophores production [64]. Hydrogen cyanide ( $\mathrm{HCN}$ ) is defined as a volatile secondary metabolite secreted by various rhizosphere bacterial species. It is characterized by its efficacy in suppression of soilborne pathogenic fungi through blocking the electron transport system and hence disrupting the supply of the cell by energy which ultimately to cell death [65]. Data showed that all selected rhizosphere bacterial strains have the ability to produce HCN with different degrees due to the color change of filter paper from deep yellow to reddishbrown (Table 2). Recently, various rhizosphere bacterial species are recorded as positive for HCN production such as Aeromonas, Pseudomonas, Bacillus, Alcaligenes, and Rhizobium [66]. 

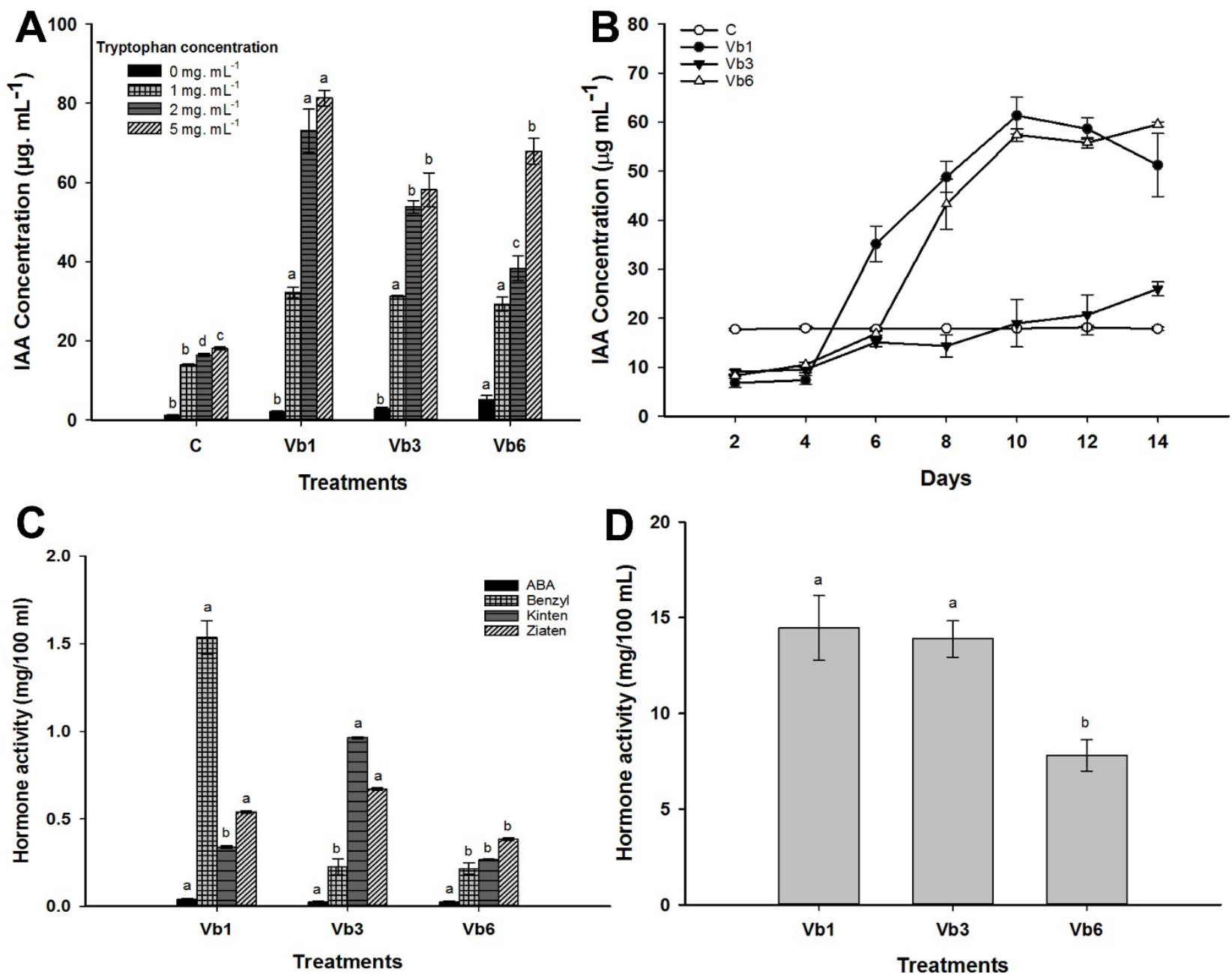

Figure 4: Phytohormones production by three rhizospheric bacterial species $\mathrm{Vb1}, \mathrm{Vb} 3$, and $\mathrm{Vb6}$. A) denote the qualitative production of IAA at different concentrations of tryptophan $\left(0,1,2\right.$, and $\left.5 \mathrm{mg} \mathrm{ml}^{-1}\right)$; B) denote the quantitative production of IAA at different interval times in presence of $5 \mathrm{mg} \mathrm{ml}^{-1}$ tryptophan, C) denote the production of ABA, Benzyl, Kinten, and Ziaten phytohormones detected by HPLC analysis, D) denote the production of $\mathrm{GA}_{3}$ detected by HPLC. Bars with the different letters are significantly different $(p \leq 0.05)$. Error bars indicate means $\pm \mathrm{SE}(n=3)$.

The ability of rhizosphere bacterial strains to produce auxin and cytokinin is a promising tool to study the profound effect of these strains on plant growth [67]. Indole-3-acetic acid (IAA) is considered the main auxins synthesized by plants and has a profound role in leaf formation, root initiation, embryo development, phototropism, fruit development, geotropism, abscission. It has a positive impact on the root length, increases root branches, root laterals, and root hair that facilitate the nutrient uptake from the surrounding environment [68]. The efficacy of three rhizospheric bacterial strains Vb1, $\mathrm{Vb} 3$, and Vb6 to produce IAA were screened qualitatively at broth media in the absence and presence of L-tryptophan $\left(0,1,2\right.$, and $\left.5 \mathrm{mg} \mathrm{ml}^{-1}\right)$ as a precursor for IAA after 15 days. Data represented in Fig. (4A) showed that the maximum
IAA production in absence of L-tryptophan was achieved for bacterial isolate Vb6 with a value of $5.2 \pm 1.03 \mu \mathrm{g} \mathrm{ml}^{-1}$ and this concentration was increased up to $67.9 \pm 3.3 \mu \mathrm{g} \mathrm{ml}^{-1}$ at $5 \mathrm{mg} \mathrm{ml}^{-1} \mathrm{~L}$-tryptophan. Moreover, the IAA production by bacterial strains $\mathrm{Vb} 1$ and $\mathrm{Vb} 3$ was increased from 2.1 \pm 0.2 and $2.8 \pm 0.4 \mu \mathrm{g} \mathrm{ml}^{-1}$ in absence of L-tryptophan to $81.3 \pm 1.9$ and $58.2 \pm 4.3 \mu \mathrm{g} \mathrm{ml}^{-1}$ in presence of $5 \mathrm{mg} \mathrm{ml}^{-1}$ tryptophan respectively (Fig. 4A). Compatible with our study, the IAA production by $B$. siamensis was increased in liquid media supplemented with L-tryptophan as compared with those without L-tryptophan, and the highest IAA production was achieved at $250 \mu \mathrm{g} \mathrm{ml}^{-1}$ [69].

According to qualitative assay, the concentration of $5 \mathrm{mg} \mathrm{ml}^{-1} \mathrm{~L}$-tryptophan is the best for higher IAA production and hence it was selected to investigate the quantitative 
IAA assay. Analysis of variance showed that the maximum IAA concentration was recorded at 10, 14, and 14 days for rhizospheric bacterial strains $\mathrm{Vb} 1, \mathrm{Vb} 3$, and $\mathrm{Vb} 6$ with values of $61.4 \pm 3.7,25.9 \pm 1.4$, and $59.6 \pm 0.5 \mu \mathrm{g} \mathrm{ml}^{-1}$, respectively.

Furthermore, the rhizospheric bacterial strains were quantitative screening for their efficacy to produce various phytohormones using HPLC analysis. Data analysis showed that the successful rhizospheric bacterial species Vb1, Vb3, and Vb6 to produce ABA, Benzyl, Kinten, Ziaten, and $\mathrm{GA}_{3}$ with values of $(0.04 \pm 0.01,0.03 \pm 0.01$, and $0.02 \pm 0.01 \mathrm{mg} / 100 \mathrm{ml}),(1.53 \pm 0.1,0.23 \pm 0.05$, and $0.22 \pm 0.03$ $\mathrm{mg} / 100 \mathrm{ml}),(0.34 \pm 0.01,0.96 \pm 0.01$, and $0.27 \pm 0.01 \mathrm{mg} / 100$ $\mathrm{ml}),(0.54 \pm 0.01,0.67 \pm 0.01$, and $0.38 \pm 0.01 \mathrm{mg} / 100 \mathrm{ml})$, and (14.45 $\pm 1.6,13.88 \pm 0.9$, and $7.80 \pm 0.8 \mathrm{mg} / 100 \mathrm{ml}$ ), respectively (Fig. 4 B and C). The ABA has an important role in improving plant adaptation under various stresses and regulating plant growth [70]. Also, Gibberellic acid is another phytohormone that has a critical role in ameliorating different stress, directly affects plant growth, plant yield, nitrogen metabolism, and mineral nutrition [71]. The efficacy of rhizosphere bacteria strains to secrete different phytohormones are mentioned in different published studies [70, 72, 73]. Based on the above plant growth-promoting traits of three rhizosphere bacterial strains can be use of these strains as bioinoculant to increase plant growth and hence increase the tolerance of a plant to phytopathogens infection.

\section{Biocontrol of Fusarium wilt in Vicia faba L. plant using rhizosphere bacterial isolates.}

\section{Greenhouse experiment.}

The efficacy of plant growth-promoting rhizobacteria Vb1, $\mathrm{Vb} 3$, and $\mathrm{Vb} 6$ to reduce the wilt disease severity caused by $F$. oxysporum was investigated under greenhouse conditions. Data analysis showed that the treatment of Vicia faba (faba bean) seeds with rhizosphere strains have the efficacy to protect the plant from Fusarium wilt with percentages of 70.0, 60.13, and 65.2\% for $\mathrm{Vb} 1, \mathrm{Vb} 3$, and $\mathrm{Vb} 6$ respectively (Table 3). Interestingly, the treatment of seeds with bacterial consortium decreases the Fusarium wilt disease severity with a percentage of $82 \%$ (Table 3). Similarly, the rhizospheric bacteria strain Bacillus thuringiensis strain BtMB9 and Acinetobacter calcoaceticus strain AcDB3 have the efficacy to decrease the Fusarium wilt disease severity in tomato, whereas the bacterial combination can highly decrease disease severity than separate one [50]. The obtained results indicated that the rhizosphere soil of the
Table 3: Effect of rhizospheric bacterial strains Vb1, Vb3, and Vb6 on disease severity and protection of faba bean plants infected with Fusarium oxysporum under greenhouse conditions.

\begin{tabular}{|c|c|c|}
\hline Treatments & $\begin{array}{l}\text { Fusarium wilt } \\
\text { severity }\end{array}$ & Protection (\%) \\
\hline $\begin{array}{l}\text { Un infected faba bean plant } \\
\text { (control) }\end{array}$ & $0.00^{\mathrm{e}}$ & $100^{\mathrm{a}}$ \\
\hline B. velezensis $\mathrm{Vb} 1+F$. oxysporum & $30.0 \pm 2.0^{c}$ & $70.00^{c}$ \\
\hline $\begin{array}{l}\text { B. paramycoides } \mathrm{Vb} 3+F \text {. } \\
\text { oxysporum }\end{array}$ & $39.9 \pm 1.8^{\mathrm{a}}$ & $60.13^{\mathrm{e}}$ \\
\hline $\begin{array}{l}\text { B. paramycoides } \mathrm{Vb} 6+F \text {. } \\
\text { oxysporum }\end{array}$ & $34.8 \pm 3.1^{\mathrm{b}}$ & $65.20^{d}$ \\
\hline $\begin{array}{l}\text { Mix }(\mathrm{Vb} 1+\mathrm{Vb} 3+\mathrm{Vb} 6)+F \\
\text { oxysporum }\end{array}$ & $18.0 \pm 2.0^{d}$ & $82^{\mathrm{b}}$ \\
\hline
\end{tabular}

Values within the same column with different letters are significantly different $(p \leq 0.05)$, values are means $\pm \operatorname{SD}(n=3)$.

same plant is the proper source to isolate bacterial species used in antagonists [74]. Although some investigators reported that the antagonistic bacterial species used in the control of phytopathogens can come from rhizosphere soil of different plants [75]. Previous studies reported the high efficacy of Bacillus spp. to be used in biocontrol of Fusarium wilt disease caused by $F$. oxysporum under greenhouse conditions [50, 76]. Furthermore, Bacillus siamensis has the efficacy to decrease the disease severity of tobacco brown spots caused by Alternaria alternata under greenhouse conditions [77]. Also, rhizosphere Bacillus amyloliquefaciens was used to significantly decrease the Fusarium wilt disease severity caused by F. oxysporum under greenhouse experiment [78]. To the best of our knowledge, this is the first report that uses the three rhizosphere bacterial strains $B$. velezensis and B. paramycoides to control Fusarium wilt caused by $F$. oxysporum under greenhouse conditions.

\section{Field experiment}

Data represented in Table 4 showed the potency of $B$. velezensis $\mathrm{Vb1}$, B. paramycoides $\mathrm{Vb} 3$, and B. paramycoides Vb6 to improve $F$. oxysporum-infected faba bean plants either separately or in a consortium. Inoculation of faba bean seeds with rhizospheric bacterial strains and planting into $F$. oxysporum-infected soil causes a significant increase in plant heights, the number of pods/ plant, and fresh and dry weight as compared with those planting into infected soil without bacterial inoculation. For instance, inoculation with separate bacterial species 
Table 4: The morphological characteristics and wilt disease severity of faba bean plant due to treatment with three rhizospheric bacterial strains Vb1, Vb3, and Vb6 (individually or in a consortium) against $F$. oxysporum.

\begin{tabular}{|c|c|c|c|c|c|c|}
\hline Treatment & Plant height $(\mathrm{cm})$ & Pods/plant & Fresh weight (g) & Dry weight (g) & Wilt severity (\%) & Protection (\%) \\
\hline Healthy plant & $83.3 \pm 2.1^{f}$ & $21.0 \pm 1.0^{d}$ & $51.7 \pm 1.2^{\mathrm{e}}$ & $18.0 \pm 2.6^{d}$ & $0.0 \pm 0.0^{\mathrm{g}}$ & $100^{\mathrm{a}}$ \\
\hline Infected plant & $64.7 \pm 1.5^{\mathrm{g}}$ & $12.3 \pm 1.5^{\mathrm{e}}$ & $38.7+2.1^{f}$ & $13.3+1.5^{\mathrm{e}}$ & $71.7 \pm 2.1^{\mathrm{a}}$ & $28.3^{\mathrm{g}}$ \\
\hline Vb1+F. oxysporum & $88.7 \pm 0.6 d^{e}$ & $23.0 \pm 1.0^{c}$ & $57.3+2.1^{\mathrm{d}}$ & $22.0+3.0^{c}$ & $32.3 \pm 0.6^{\mathrm{d}}$ & $67.7^{d}$ \\
\hline Vb3 + F. oxysporum & $89.0 \pm 1.0^{d}$ & $23.7 \pm 2.1^{c}$ & $57.7+2.1^{\mathrm{d}}$ & $22.7+2.1^{c}$ & $41.7+1.2^{b}$ & $58.3^{f}$ \\
\hline Vb6 + F. oxysporum & $86.0 \pm 1.0^{\text {ef }}$ & $22.0 \pm 2.6^{\mathrm{cd}}$ & $56.3+3.1^{d}$ & $21.0+3.0^{c}$ & $37.0+1.7^{c}$ & $63.0^{\mathrm{e}}$ \\
\hline$(\mathrm{Vb} 1+\mathrm{Vb} 3)+F$. oxysporum & $93.0 \pm 2.6^{c}$ & $24.7 \pm 1.5^{c}$ & $60.3+2.5^{c}$ & $23.3+3.2^{\mathrm{b}}$ & $29.0+1.0^{d}$ & $71^{\mathrm{c}}$ \\
\hline$(\mathrm{Vb} 1+\mathrm{Vb} 6)+F$. oxysporum & $96.7 \pm 1.2^{\mathrm{b}}$ & $26.3 \pm 1.5^{b}$ & $65.7+1.5^{b}$ & $24.3+2.5^{b}$ & $26.3+0.6^{\mathrm{e}}$ & $73.7^{c}$ \\
\hline$(\mathrm{Vb} 3+\mathrm{Vb} 6)+$ F. oxysporum & $97.3 \pm 1.5^{\mathrm{b}}$ & $28.7 \pm 1.6^{b}$ & $66.7+3.1^{b}$ & $26.3+2.1^{b}$ & $31.3+1.2^{\mathrm{d}}$ & $68.7^{d}$ \\
\hline (V-mix) + F. oxysporum & $113.0 \pm 2.0^{\mathrm{a}}$ & $33.3 \pm 2.1^{\mathrm{a}}$ & $75.7+1.5^{\mathrm{a}}$ & $33.7+1.5^{\mathrm{a}}$ & $16.7+1.2^{f}$ & $83.3^{\mathrm{b}}$ \\
\hline
\end{tabular}

Healthy plant meaning planting of faba bean in soil without rhizobacterial strains and $F$. oxysporum; Infected plant meaning planting of faba bean in F. oxysporum-infected soil in absence of rhizobacterial strains; $\mathrm{Vb} 1$ is B. velezensis; $\mathrm{Vb} 3 \mathrm{is} \mathrm{B.} \mathrm{paramycoides,} \mathrm{and} \mathrm{Vb} 6$ is $B$. paramycoides. Values within the same row with different letters are significantly different $(p \leq 0.05)$, values are means $\pm \operatorname{SD}(n=3)$.

enhance plant height with percentages of $21.3 \%-24.3 \%$, whereas the bacterial consortium highly improves faba bean plant height with percentages of $28.3 \%-48.3 \%$ and the highest significant value was recorded for V-mix treatment (Vb1+Vb3+Vb6) as compared with the infected plant (plant sowing in infected soil in absence of bacterial strains). Moreover, the number of pods/ plants were highly reduced in the infected plant $(12.3 \pm 1.5)$ as compared with a healthy plant $(21.0 \pm 1.0)$. The presence of plant growth-promoting rhizobacterial strains causes a significant increase in the number of pods as compared with healthy plants and the highest number was recorded for the bacterial consortium.

On the other hand, the fresh weight and dry weight of healthy and infected faba bean plants after 60 days of sowing were $(51.7 \pm 1.2 \mathrm{~g}$ and $18.0 \pm 2.6 \mathrm{~g})$ and $(38.7+2.1 \mathrm{~g}$ and $13.3+1.5 \mathrm{~g}$ ), respectively. The presence of $F$. oxysporum in absence of bacterial rhizospheric strains has a negative impact on all morphological characteristics of faba bean. Inoculation of plants with different bacterial strains $\mathrm{Vb1}$, $\mathrm{Vb3}$, and Vb6 has been significantly improving fresh and dry weight in presence of fungus. For instance, the presence of $B$. velezensis $\mathrm{Vb} 1$ improves the fresh weight and dry weight with values of $18.6 \%$ and $8.7 \%$ respectively, whereas the bacterial consortium (V-mix) increases the fresh weight and dry weight with percentages of $37 \%$ and $20.4 \%$ respectively in presence of $F$. oxysporum strain (Table 4). The obtained data are in harmony with those reported that the rhizobacterial strains Rhizobium sp., Bacillus pumilus, and Pseudomonas alcaligenes have the efficacy to improve the number of pods, dry weight, fresh weight, and plant height of lentil in presence of Fusarium oxysporum causing wilt disease [79]. Similarly, rhizobacterial strain Bacillus sp. SJ-5 was used to biocontrol disease caused by Fusarium oxysporum \& Rhizoctonia solani in soybean plants [80].

The current study showed that the three rhizospheric Bacillus spp. have the potency to improve the growth performance of the $F$. oxysporum-infected faba bean plant. This phenomenon can be attributed to antagonistic activity between rhizospheric bacteria and pathogens, producing lytic enzymes, secretion of bioactive inhibitory compounds, or competition between bacteria and pathogenic fungi on essential nutrients [81, 82]. Bacillus spp. are considered the most common rhizospheric bacterial strains used to decrease the wilting disease caused by $F$. oxysporum in various plants $[83,84]$. The various published studies reported that the Bacillus spp. have various suppressive mechanisms including producing volatile substances, induction of systematic resistance, stimulating plant growth, and aggressive plant roots colonization $[13,79]$.

The planting of faba bean in infected soil with $F$. oxysporum caused $71.7 \pm 2.1$ wilt severity after 60 days of planting (Table 4). The inoculation of faba bean seeds with plant growth-promoting rhizospheres causes a significant decrease in wilt disease. For example, the presence of bacteria consortium V-mix (Vb1+Vb3+Vb6) has the efficacy to protect faba bean plant from wilt with percentages of $83.3 \%$, followed by bacterial treatment $\mathrm{Vb} 1+\mathrm{Vb} 6$ that reduce the wilt with a percentage of $73.7 \%$. Not only rhizobacterial consortium can reduce the wilt 
disease, but also separate species have the ability. For instance, the presence of $B$. velezensis $\mathrm{Vb} 1$ can reduce the wilt disease with a percentage of $67.7 \%$ as compared with infected plants followed by B. paramycoides Vb6 and B. paramycoides Vb3 (Table 4). Un-compatible with our study, Akköprü and Demir reported that the treatment with single rhizobacterial species was more effective than Glomus intraradices as mycorrhizal fungi or consortium between mycorrhizae and rhizosphere bacteria to biocontrol of $F$. oxysporum f. sp. lycopersici in tomato plant [85]. The obtained results are in harmony with those recorded by Khalil and co-authors, who reported that the rhizospheric bacterial strains B. siamensis BsiDA2 and $B$. subtilis BsTA16 have significantly reduced wilt disease in tomatoes caused by Fusarium oxysporum spp. lycopersici [50]. The rhizospheric Bacillus spp. are used by various researchers to biocontrol wilt disease caused by $F$. oxysporum in various plants under greenhouse and field conditions [74, 81]. In the current study, the activity of Bacillus spp. to reduce the wilt disease can be attributed to producing siderophores, HCN, hydrolytic enzymes, and ammonia which help in suppressive phytopathogens.

\section{Conclusion}

In the current study, seven Fusarium spp. were isolated from the infected roots of the Vicia faba L. plant collected from Sinai governorate, Egypt. Two F. oxysporum strains that caused the highest disease severity of Fusarium wilt were selected. Then, three rhizobacterial species of Bacillus which showed the highest plant growthpromoting properties and antagonistic activities were isolated from the rhizospheric soil of the healthy faba bean plant. Biocontrol of Fusarium wilt in bean plants using the selected rhizobacterial species of Bacillus under the greenhouse and field experiments revealed the efficacy of plant growth-promoting rhizobacteria to reduce the wilt disease severity caused by F. oxysporum. Species of rhizobacteria being associated with the healthy plant roots, which promote plant growth and induce the plant defense against microbial pathogens should be subjected to further investigation.

Author Contribution: Saad El-Din Hassan and Amr Fouda: Conceptualization, Data curing, Formal analysis, Investigation, methodology, Project administration, Resources, Software, Validation, Visualization, Writingoriginal draft, Writing -review and editing; Mostafa Mohamed El-Sersawy: Data curing, Formal analysis, methodology, Resources, Software, Validation, Visualization, Writing-original draft; Amr Mahmoud Abd El-Gwad and Abbas Ahmed El-Ghamry: Conceptualization, Data curing, Investigation, Resources, Validation, Visualization, Writing-original draft.

Conflict of Interest: Authors state no conflict of interest.

Data Availability Statement: The datasets generated during and/or analysed during the current study are available from the corresponding author on reasonable request.

\section{References}

1. Alexandratos N, Bruinsma J. World agriculture towards 2030/2050: the 2012 revision. ESA Working paper No. 12-03. Rome, FAO. 2012.

2. Layek J, Das A, Mitran T, Nath C, Meena RS, Yadav GS, et al. Cereal+Legume Intercropping: An Option for Improving Productivity and Sustaining Soil Health. In: Meena RS, Das A, Yadav GS, Lal R, editors. Legumes for Soil Health and Sustainable Management. Singapore: Springer Singapore; 2018. pp. 347-86.

3. Etesami H, Emami S, Alikhani HA. Potassium solubilizing bacteria (KSB): Mechanisms, promotion of plant growth, and future prospects A review. J Soil Sci Plant Nutr. 2017;17(4):897911.

4. Singh Mavi M, Singh G, Singh BP, Singh Sekhon B, Choudhary $\mathrm{OP}$, Sagi S, et al. Interactive effects of rice-residue biochar and $\mathrm{N}$-fertilizer on soil functions and crop biomass in contrasting soils. J Soil Sci Plant Nutr. 2018;18 ahead:41-59.

5. Hamza MF, Hamad DM, Hamad NA, Abdel-Rahman AA, Fouda A, Wei $Y$, et al. Functionalization of magnetic chitosan microparticles for high-performance removal of chromate from aqueous solutions and tannery effluent. Chem Eng J. 2022;428:131775.

6. Fouda A, Hassan SE, Saied E, Hamza MF. Photocatalytic degradation of real textile and tannery effluent using biosynthesized magnesium oxide nanoparticles (MgO-NPs), heavy metal adsorption, phytotoxicity, and antimicrobial activity. J Environ Chem Eng. 2021;9(4):105346.

7. Saied E, Fouda A, Alemam AM, Sultan MH, Barghoth MG, Radwan AA, et al. Evaluate the Toxicity of Pyrethroid Insecticide Cypermethrin before and after Biodegradation by Lysinibacillus cresolivuorans Strain HIS7. Plants. 2021 Sep;10(9):1903.

8. Fouda A, Hassan SE, Saied E, Azab MS. An eco-friendly approach to textile and tannery wastewater treatment using maghemite nanoparticles ( $\gamma$-Fe203-NPs) fabricated by Penicillium expansum strain (K-w). J Environ Chem Eng. 2021;9(1):104693.

9. Katiyar D, Hemantaranjan A, Singh B. Plant growth promoting Rhizobacteria-an efficient tool for agriculture promotion. Adv Plants Agric Res. 2016;4(6):426-34.

10. Bhardwaj D, Ansari MW, Sahoo RK, Tuteja N. Biofertilizers function as key player in sustainable agriculture by improving 
soil fertility, plant tolerance and crop productivity. Microb Cell Fact. 2014 May;13(1):66.

11. Pathan SI, Ceccherini MT, Sunseri F, Lupini A. Rhizosphere as Hotspot for Plant-Soil-Microbe Interaction. In: Datta R, Meena RS, Pathan SI, Ceccherini MT, editors. Carbon and Nitrogen Cycling in Soil. Singapore: Springer Singapore; 2020. pp. 17-43.

12. Mahgoub HA, Fouda A, Eid AM, Ewais EE, Hassan SE. Biotechnological application of plant growth-promoting endophytic bacteria isolated from halophytic plants to ameliorate salinity tolerance of Vicia faba L. Plant Biotechnol Rep. 2021;15(6):819-43.

13. Wang H, Liu R, You MP, Barbetti MJ, Chen Y. Pathogen Biocontrol Using Plant Growth-Promoting Bacteria (PGPR): Role of Bacterial Diversity. Microorganisms. 2021 Sep;9(9):1988.

14. Guo M, Song W, Tian J. Biochar-Facilitated Soil Remediation: Mechanisms and Efficacy Variations. Front Environ Sci. 2020;8(183):521512.

15. Huang $\mathrm{CH}, \mathrm{Hsiang} \mathrm{T}$, Trevors JT. Comparative bacterial genomics: defining the minimal core genome. Antonie van Leeuwenhoek. 2013 Feb;103(2):385-98.

16. Malusá E, Vassilev N. A contribution to set a legal framework for biofertilisers. Appl Microbiol Biotechnol. 2014 Aug;98(15):6599回607.

17. Dal Cortivo C, Ferrari M, Visioli G, Lauro M, Fornasier F, Barion $\mathrm{G}$, et al. Effects of Seed-Applied Biofertilizers on Rhizosphere Biodiversity and Growth of Common Wheat (Triticum aestivum L.) in the Field. Front Plant Sci. 2020 Feb;11(72):72.

18. Meng Z, Liu Q, Zhang Y, Chen J, Sun Z, Ren C, et al. Nutritive value of faba bean (Vicia faba L.) as a feedstuff resource in livestock nutrition: A review. Food Sci Nutr. 2021 Jul;9(9):5244-62.

19. Dhull SB, Kidwai MK, Noor R, Chawla P, Rose PK. A review of nutritional profile and processing of faba bean (Vicia faba L.). Legume Science 2021; e129.

20. Niño-Sánchez J, Tello V, Casado-Del Castillo V, Thon MR, Benito EP, Díaz-Mínguez JM. Gene expression patterns and dynamics of the colonization of common bean (Phaseolus vulgaris L.) by highly virulent and weakly virulent strains of Fusarium oxysporum. Front Microbiol. 2015 Apr;6:234.

21. Xue R, Wu J, Zhu Z, Wang L, Wang X, Wang S, et al. Differentially Expressed Genes in Resistant and Susceptible Common Bean (Phaseolus vulgaris L.) Genotypes in Response to Fusarium oxysporum f. sp. phaseoli. PLoS One. 2015 Jun;10(6):e0127698.

22. Jiménez-Fernández $D$, Landa BB, Kang $S$, Jiménez-Díaz RM, Navas-Cortés JA. Quantitative and microscopic assessment of compatible and incompatible interactions between chickpea cultivars and Fusarium oxysporum f. sp. ciceris races. PLoS One. 2013 Apr;8(4):e61360.

23. Booth C. The genus fusarium commonwealth mycological institute. Kew, Surrey; 1971. p. 237.

24. Kleczewski NM, Egel DS. A Diagnostic Guide for Fusarium Wilt of Watermelon. Plant Health Prog. 2011;12(1):27.

25. Nelson PE, Toussoun TA, Marasas W. Fusarium species: an illustrated manual for identification. Penn State University Press; 1983. p. 206.

26. Mahmoud A. Evaluation of certain antagonistic fungal species for biological control of faba bean wilt disease incited by Fusarium oxysporum. Journal of Phytopathology and Pest Management. 2016;3:1-14.
27. Landa B, Hervás A, BettiolW, Jiménez-Díaz R. Antagonistic activity of Bacteria from the chickpea rhizosphere against Fusarium Oxysporum f. sp. Ciceris. Phytoparasitica. 1997;25(4):305国18.

28. Miller DN, Bryant JE, Madsen EL, Ghiorse WC. Evaluation and optimization of DNA extraction and purification procedures for soil and sediment samples. Appl Environ Microbiol. 1999 Nov;65(11):4715-24.

29. Gothwal R, Nigam V, Medicherla K, Sasmal D, Ghosh P. Screening of nitrogen fixers from rhizospheric bacterial isolates associated with important desert plants. Appl Ecol Environ Res. 2007;6(2):101-9.

30. Dilworth MJ. Acetylene reduction by nitrogen-fixing preparations from Clostridium pasteurianum. Biochim Biophys Acta. 1966 Oct;127(2):285-94.

31. Jasim B, John Jimtha C, Jyothis M, Radhakrishnan EK. Plant growth promoting potential of endophytic bacteria isolated from Piper nigrum. Plant Growth Regul. 2013;71(1):1-11.

32. Fouda A, Eid AM, Elsaied A, El-Belely EF, Barghoth MG, Azab E, et al. Plant Growth-Promoting Endophytic Bacterial Community Inhabiting the Leaves of Pulicaria incisa (Lam.) DC Inherent to Arid Regions. Plants (Basel, Switzerland) 2021;10:(1).

33. Yadav J, Verma J, Tiwari K. Effect of plant growth promoting Rhizobacteria on seed germination and plant growth Chickpea (Cicer arietinum L.) under in vitro conditions. Biol Forum. 2010;2(2):15-8.

34. Lv YL, Zhang FS, Chen J, Cui JL, Xing YM, Li XD, et al. Diversity and antimicrobial activity of endophytic fungi associated with the alpine plant Saussurea involucrata. Biol Pharm Bull. 2010;33(8):1300-6.

35. Khalil AM, Hassan SE, Alsharif SM, Eid AM, Ewais EE, Azab E, et al. Isolation and Characterization of Fungal Endophytes Isolated from Medicinal Plant Ephedra pachyclada as Plant GrowthPromoting. Biomolecules. 2021 Jan;11(2):140.

36. Kumar A, Kumar A, Devi S, Patil S, Payal C, Negi S. Isolation, screening and characterization of bacteria from Rhizospheric soils for different plant growth promotion (PGP) activities: an in vitro study. Recent Research in Science and Technology 2012;4:(1).

37. Kotasthane AS, AgrawalT, Zaidi NW, Singh US. Identification of siderophore producing and cynogenic fluorescent Pseudomonas and a simple confrontation assay to identify potential bio-control agent for collar rot of chickpea. 3 Biotech 2017;7(2):137.

38. Geetha K, Enkatesham EV, Amballa H, Hadraiah BB. Solation, screening and characterization of plant growth promoting bacteria and their effect on VignaRadita(L.) R.Wilczek. Int J Curr Microbiol Appl Sci. 2014;3:799-809.

39. Alkahtani MD, Fouda A, Attia KA, Al-Otaibi F, Eid AM, Ewais EE, et al. Isolation and Characterization of Plant Growth Promoting Endophytic Bacteria from Desert Plants and Their Application as Bioinoculants for Sustainable Agriculture. Agronomy (Basel). 2020;10(9):1325.

40. Abdel-Aziez SM, Eweda WE, Girgis MG, Abdel Ghany BF. Improving the productivity and quality of black cumin (Nigella sativa) by using Azotobacter as N2 biofertilizer. Ann Agric Sci. 2014;59(1):95-108.

41. Ma K, Kou J, Khashi U Rahman M, Du W, Liang X, Wu F, et al. Palmitic acid mediated change of rhizosphere and alleviation of Fusarium wilt disease in watermelon. Saudi J Biol Sci. 2021 Jun;28(6):3616-23. 
42. Alghamdi SS, Migdadi HM, Ammar MH, Paull JG, Siddique KH. Faba bean genomics: current status and future prospects. Euphytica. 2012;186(3):609-24.

43. Abdel-Kader MM, El-Mougy NS, Lashin SM. Essential oils and Trichoderma harzianum as an integrated control measure against faba bean root rot pathogens. J Plant Prot Res. 2011;51(3):306-13.

44. Lv J, Xiao J, Guo Z, Dong K, Dong Y. Nitrogen supply and intercropping control of Fusarium wilt in faba bean depend on organic acids exuded from the roots. Sci Rep. 2021 May;11(1):9589.

45. Stoddard FL, Nicholas AH, Rubiales D, Thomas J, VillegasFernández AM. Integrated pest management in faba bean. Field Crops Res. 2010;115(3):308-18.

46. Ismail MA, Amin MA, Eid AM, Hassan SE, Mahgoub HA, Lashin I, et al. Comparative Study between Exogenously Applied Plant Growth Hormones versus Metabolites of Microbial Endophytes as Plant Growth-Promoting for Phaseolus vulgaris L. Cells. 2021 Apr;10(5):1059.

47. Lee T, Park D, Kim K, Lim SM, Yu NH, Kim S, et al. Characterization of Bacillus amyloliquefaciens DA12 Showing Potent Antifungal Activity against Mycotoxigenic Fusarium Species. Plant Pathol J. 2017 Oct;33(5):499-507.

48. Islam MA, Nain Z, Alam MK, Banu NA, Islam MR. In vitro study of biocontrol potential of rhizospheric Pseudomonas aeruginosa against Fusarium oxysporum f. sp. cucumerinum. Egypt J Biol Pest Control. 2018;28(1):90.

49. Xue C, Penton CR, Shen Z, Zhang R, Huang Q, Li R, et al. Manipulating the banana rhizosphere microbiome for biological control of Panama disease. Sci Rep. 2015 Aug;5(1):11124.

50. Khalil MM, Fierro-Coronado RA, Peñuelas-Rubio O, Villa-Lerma AG, Plascencia-Jatomea R, Félix-Gastélum R, et al. Rhizospheric bacteria as potential biocontrol agents against Fusarium wilt and crown and root rot diseases in tomato. Saudi J Biol Sci. 2021 Dec;28(12):7460-71.

51. Fira D, Dimkić I, Berić T, Lozo J, Stanković S. Biological control of plant pathogens by Bacillus species. J Biotechnol. 2018 Nov;285:44-55.

52. Luo W, Liu L, Qi G, Yang F, Shi X, Zhao X. Embedding Bacillus velezensis $\mathrm{NH}-1$ in Microcapsules for Biocontrol of Cucumber Fusarium Wilt. Appl Environ Microbiol. 2019 Apr;85(9):e03128-18.

53. Beneduzi A, Ambrosini A, Passaglia LM. Plant growth promoting rhizobacteria (PGPR): their potential as antagonists and biocontrol agents. Genet Mol Biol. 2012 Dec;35(4 (suppl) suppl):1044-51.

54. Li X, Geng X, Xie R, Fu L, Jiang J, Gao L, et al. The endophytic bacteria isolated from elephant grass (Pennisetum purpureum Schumach) promote plant growth and enhance salt tolerance of Hybrid Pennisetum. Biotechnol Biofuels. 2016 Sep;9(1):190.

55. Paul D, Sinha SN. Isolation and characterization of phosphate solubilizing bacterium Pseudomonas aeruginosa KUPSB12 with antibacterial potential from river Ganga, India. Ann Agrar Sci. 2017;15(1):130-6.

56. Khan MA, Asaf S, Khan AL, Ullah I, Ali S, Kang SM, et al. Alleviation of salt stress response in soybean plants with the endophytic bacterial isolate Curtobacterium sp. SAK1. Ann Microbiol. 2019;69(8):797-808.

57. Passari AK, Mishra VK, Leo VV, Gupta VK, Singh BP. Phytohormone production endowed with antagonistic potential and plant growth promoting abilities of culturable endophytic bacteria isolated from Clerodendrum colebrookianum Walp. Microbiol Res. 2016 Dec;193:57-73.

58. Nannipieri P. Functions of microbial communities and their importance to soil. Perspect Agric Vet Sci Nutr Nat Resour. 2007;2(050). https://doi.org/10.1079/PAVSNNR20072050.

59. Egamberdieva D, Renella G, Wirth S, Islam R. Enzyme Activities in the Rhizosphere of Plants. In: Shukla G, Varma A, editors. Soil Enzymology. Berlin, Heidelberg: Springer Berlin Heidelberg; 2011. pp. 149-66.

60. Glick BR. Plant growth-promoting bacteria: mechanisms and applications. Scientifica (Cairo). 2012;2012:963401.

61. Egamberdieva D, Kamilova F, Validov S, Gafurova L, Kucharova $Z$, Lugtenberg B. High incidence of plant growth-stimulating bacteria associated with the rhizosphere of wheat grown on salinated soil in Uzbekistan. Environ Microbiol. 2008 Jan;10(1):1-9.

62. Solans M, Scervino JM, Messuti MI, Vobis G, Wall LG. Potential biocontrol actinobacteria: rhizospheric isolates from the Argentine Pampas lowlands legumes. J Basic Microbiol. 2016 Nov;56(11):1289-98.

63. Venkat Kumar S, Menon S, Agarwal H, Gopalakrishnan D. Characterization and optimization of bacterium isolated from soil samples for the production of siderophores. ResourceEfficient Technologies. 2017;3(4):434-9.

64. Sulochana MB, Jayachandra SY, Kumar SK, Dayanand A. Antifungal attributes of siderophore produced by the Pseudomonas aeruginosa JAS-25. J Basic Microbiol. 2014 May;54(5):418-24.

65. Abd El-Rahman AF, Shaheen HA, Abd El-Aziz RM, Ibrahim DS. Influence of hydrogen cyanide-producing rhizobacteria in controlling the crown gall and root-knot nematode, Meloidogyne incognita. Egypt J Biol Pest Control. 2019;29(1):41.

66. Alemu F. Isolation of Pseudomonas flurescens from rhizosphere of faba bean and screen their hydrogen cyanide production under in vitro study, Ethiopia. Am J Life Sci. 2016;4(2):13-9.

67. Wahyudi AT, Astuti RP, Widyawati A, Mery A, Nawangsih AA. Characterization of Bacillus sp. strains isolated from rhizosphere of soybean plants for their use as potential plant growth for promoting rhizobacteria. J Microbiol Antimicrob. 2011;3(2):34-40.

68. Datta C, Basu PS. Indole acetic acid production by a Rhizobium species from root nodules of a leguminous shrub, Cajanus cajan. Microbiol Res. 2000 Jul;155(2):123-7.

69. Suliasih; Widawati, S., Isolation of Indole Acetic Acid (IAA) producingBacillus siamensisfrom peat and optimization of the culture conditions for maximum IAA production. IOP Conf Ser Earth Environ Sci. 2020;572:012025.

70. Egamberdieva D, Wirth SJ, Alqarawi AA. Abd_Allah, E. F.; Hashem, A., Phytohormones and Beneficial Microbes: Essential Components for Plants to Balance Stress and Fitness. Front Microbiol. 2017;8(2104).

71. Iqbal M, Ashraf M. Gibberellic acid mediated induction of salt tolerance in wheat plants: Growth, ionic partitioning, photosynthesis, yield and hormonal homeostasis. Environ Exp Bot. 2013;86:76-85.

72. Boiero L, Perrig D, Masciarelli O, Penna C, Cassán F, Luna V. Phytohormone production by three strains of Bradyrhizobium japonicum and possible physiological and 
technological implications. Appl Microbiol Biotechnol. 2007 Mar;74(4):874⿴囗80.

73. Naz I, Bano A, Ul-Hassan T. Isolation of phytohormones producing plant growth promoting rhizobacteria from weeds growing in Khewra salt range, Pakistan and their implication in providing salt tolerance to Glycine max L. Afr J Biotechnol. 2009;8(21).

74. Jangir $M$, Pathak $R$, Sharma S, Sharma S. Biocontrol mechanisms of Bacillus sp., isolated from tomato rhizosphere, against Fusarium oxysporum f. sp. lycopersici. Biol Control. 2018;123:60-70.

75. Ben Abdallah R, Jabnoun-Khiareddine H, Nefzi A, Mokni-Tlili S, Daami-Remadi M. Endophytic bacteria from Datura stramonium for Fusarium wilt suppression and tomato growth promotion. J Microb Biochem Technol. 2016;8(1):30-41.

76. Kamali M, Ahmadi J, Naeimi S, Guo D. Characterization of Bacillus Isolates from the Rhizosphere of Tomato Suppressing Fusarium Wilt Disease. Acta Phytopathol Entomol Hung. 2019;54(1):53-68.

77. Xie Z, Li M, Wang D, Wang F, Shen H, Sun G, et al. Biocontrol efficacy of Bacillus siamensis LZ88 against brown spot disease of tobacco caused by Alternaria alternata. Biol Control. 2021;154:104508.

78. Wan T, Zhao H, Wang W. Effect of biocontrol agent Bacillus amyloliquefaciens SN16-1 and plant pathogen Fusarium oxysporum on tomato rhizosphere bacterial community composition. Biol Control. 2017;112:1-9.

79. Akhtar MS, Shakeel U, Siddiqui Z. Biocontrol of Fusarium wilt by Bacillus pumilus, Pseudomonas alcaligenes and Rhizobium sp. on lentil. Turk J Biol. 2010;34:1-7.

80. Jain S, Vaishnav A, Kumari S, Varma A, Tuteja N, Choudhary DK. Chitinolytic Bacillus-Mediated Induction of Jasmonic Acid and Defense-Related Proteins in Soybean (Glycine max L. Merrill) Plant Against Rhizoctonia solani and Fusarium oxysporum. J Plant Growth Regul. 2017;36(1):200-14.

81. Ali S, Hameed S, Shahid M, Iqbal M, Lazarovits G, Imran A. Functional characterization of potential PGPR exhibiting broad-spectrum antifungal activity. Microbiol Res. 2020 Feb;232:126389.

82. Eid AM, Fouda A, Abdel-Rahman MA, Salem SS, Elsaied $A$, Oelmüller R, et al. Harnessing Bacterial Endophytes for Promotion of Plant Growth and Biotechnological Applications: an Overview. Plants. 2021 May;10(5):935.

83. Bapat S, Shah AK. Biological control of fusarial wilt of pigeon pea by Bacillus brevis. Can J Microbiol. 2000 Feb;46(2):125-32.

84. Bukhat S, Imran A, Javaid S, Shahid M, Majeed A, Naqqash T. Communication of plants with microbial world: exploring the regulatory networks for PGPR mediated defense signaling. Microbiol Res. 2020 Sep;238:126486.

85. Akköprü A, Demir S. Biological Control of Fusarium Wilt Caused by Fusarium oxysporum f.sp. lycopersici in Tomato by AMF Glomus intraradices and Some Rhizobacteria. J Phytopathol. 2005;153(9):544⿴囗十0. 